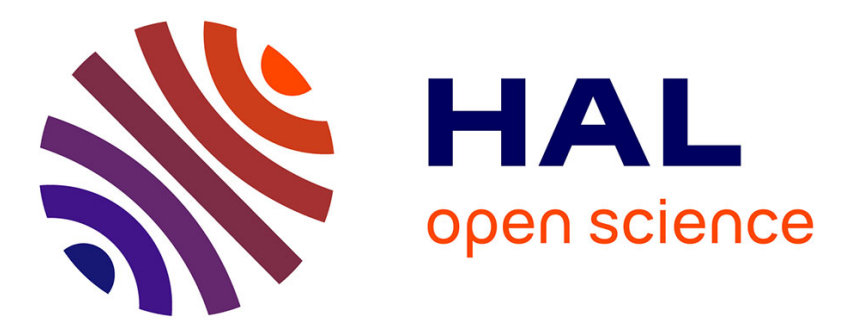

\title{
Wage Premium and Wage Penalty in Marriage versus Cohabitation
}

\author{
Carole Bonnet, Bruno Jeandidier, Anne Solaz
}

\section{To cite this version:}

Carole Bonnet, Bruno Jeandidier, Anne Solaz. Wage Premium and Wage Penalty in Marriage versus Cohabitation. Revue d'Economie Politique, 2018, 128 (5), pp.745-775. 10.3917/redp.285.0745 . hal02978180

\section{HAL Id: hal-02978180 \\ https://hal.univ-lorraine.fr/hal-02978180}

Submitted on 6 Jan 2022

HAL is a multi-disciplinary open access archive for the deposit and dissemination of scientific research documents, whether they are published or not. The documents may come from teaching and research institutions in France or abroad, or from public or private research centers.
L'archive ouverte pluridisciplinaire HAL, est destinée au dépôt et à la diffusion de documents scientifiques de niveau recherche, publiés ou non, émanant des établissements d'enseignement et de recherche français ou étrangers, des laboratoires publics ou privés. 


\title{
Wage premium and wage penalty in marriage versus cohabitation
}

\author{
Carole BONNET (INED), \\ Bruno JEANDIDIER (BETA, CNRS, Université de Lorraine), \\ Anne SOLAZ (INED) $)^{1}$
}

\begin{abstract}
Empirical evidence has shown that married men generally earn more and married women earn less than their unmarried counterparts. However, the control group of "not married" differs between studies, over time and between countries, such that the message remains somewhat fuzzy. It is not clear whether the type of union or the fact of being in a union is responsible for these wage penalties and premiums. This article aims to analyze whether marriage pays more than cohabitation in a country such as France, where cohabiting and married partnerships have both coexisted for years. Thanks to a rich dataset with information on both the marital and work history of both partners, we are able to estimate the effect on hourly wages of being married relative to being in a cohabiting union. Taking into account selections into marriage (rather than cohabitation) and into the labor market with a possible differential in sharing of paid work within the couple, our results show that the men's marriage premium is due entirely to a positive selection into marriage. While the process of within-couple marital specialization strongly reduces a woman's hourly wage, there is no evidence of any additional marriage penalty for women. The within-couple gender wage gap is similar for married and cohabiting partners, after controlling for selection into marriage.
\end{abstract}

\section{Résumé}

Les travaux empiriques montrent que les hommes mariés gagnent généralement plus que les autres et que les femmes mariées gagnent moins. Cependant, le groupe de contrôle des " non marié » diffère selon les études, dans le temps et entre les pays, si bien qu'il n'est pas aisé d'identifier si c'est le type d'union ou le fait d'être en couple qui est à l'origine de ces pénalités ou primes salariales. Cet article vise à analyser si les personnes mariées ont des salaires horaires différents des personnes en couple non marié, en France, pays dans lequel les deux formes d'unions coexistent depuis longtemps. A partir des données de l'enquête Famille et Employeurs (2005), contenant des informations sur l'histoire conjugale et professionnelle des deux partenaires, nous estimons l'effet du mariage sur le salaire horaire des personnes en couple. En tenant compte de la sélection dans le mariage (plutôt que dans la cohabitation) et sur le marché du travail, et d'un différentiel possible de spécialisation conjugale, nos résultats montrent que la prime au mariage des hommes est entièrement due à une sélection positive dans ce type d'union. La division sexuée du travail au sein du couple diminue fortement le salaire horaire des femmes mais nous ne mettons en évidence aucune pénalité supplémentaire liée au mariage. L'écart salarial entre les partenaires est similaire qu'ils soient mariés ou non mariés, une fois la sélection dans le mariage contrôlée.

JEL Codes: J31, J12

Keywords: Marriage, Cohabitation, Specialization, Marriage Premium, Earnings.

\footnotetext{
${ }^{1}$ Research carried out with support from the COMPRES project of the ANR (the French National Research Agency).
} 


\section{Introduction}

As unmarried co-resident couples have become more and more common in many European countries (Perelli-Harris et al. 2012), cohabiting couples are now quite similar in many aspects to those that are married: their unions have become more stable and they may have children, among other characteristics. Unmarried parenthood is becoming common, with $60 \%$ of children having been born outside marriage in France, mostly in cohabitating unions. The parental rights of both types of unions are also converging. Couples can now freely choose the type of union (i.e., married or not) even if they decide to have children.

However, differences remain between the married and unmarried in cases of couple dissolution. In particular, legal rules (welfare state policies and laws) were implemented to "protect" the married spouse who invests the most in unpaid work (still mainly women) from the potential economic consequences of union dissolution (Kandil \& Périvier, 2017). Even though the status of PACS (Pacte Civil de Solidarite - the French civil partnership created in 1999) progressively extended some protections associated with marriage - in terms of taxation, for instance, some legal rules are still reserved for marriage. Two of them are particularly illustrative, namely in regard to the death of a spouse and in cases of separation. Following the death of a married spouse, a part of the pension of the deceased spouse (called the survivor's pension) is paid to the surviving spouse. In the event of divorce, the law sets up private transfers between spouses: One spouse may be compelled to pay the other a "spousal alimony" by decision of the family court judge. This transfer aims to compensate the spouse who loses out financially when a marriage comes to an end, mainly because he or she has been more heavily engaged in unpaid domestic and parental work (and, hence, has at least partially withdrawn from the labor market).

In France, as in many countries, the idea of extending these types of compensation to unmarried couples has been regularly considered and debated. For instance, the recurrent debate on extending survivors' pension benefits to registered partners or partners in a civil union has taken place in Germany, Great Britain, Finland, Norway and France (Conseil d'Orientation des Retraites, 2008; Bonnet \& Hourriez, 2012). Extending spousal alimony has been recently discussed in Quebec, for example, in a recent report (Comité Consultatif sur le Droit de la Famille, 2015) that argues for the generalization of the system of alimony to all parental couples, regardless of their marital status. To varying degrees, this is also the case in other Canadian provinces (Balla \& Bromwich, 2002). In France, a similar argument has been put forth in an analytical note by the Centre d'Analyse Stratégique (Boisson \& Wisnia-Weill, 2012).

In order to contribute to this debate and possibly advance arguments in favor of or against this generalization, it is necessary to ask whether there is effectively any difference between married and unmarried couples in terms of financial resources and wage differentials. According to an economic and legal approach (Bourreau-Dubois et al., 2017), the spousal alimony is necessary for reducing the possible inequality of resources between spouses as established at the time of divorce (compensation, equalization) if this inequality results from marriage (damages) ${ }^{2}$. This is why we address here the following two questions. Are marriage and cohabitation (and thus the specialization of roles during a

\footnotetext{
2 In France, alimony concerns mainly active people: In divorce judgments for the year 2013 that granted alimony, $83 \%$ of the couples comprised two spouses under the age of 60 . While spousal alimony among them is more frequent for single-earner couples (20\%) than for dual-earner couples, it is also very common (17\%) for the latter, which are by far the most numerous ( $75 \%$ of couples under 60 are dual earners). In these cases, the inequality of resources between spouses at the time of divorce (which justifies the payment of alimony) is therefore based mainly on income from activity (Survey "Prestation compensatoire: Ministère de la Justice - ANR COMPRES").
} 
couple's life together) associated with the same wage penalties/premiums? Does wage inequality between spouses differ according to marital status? Thus, we do not try in this article to show that being in a relationship has an impact on incomes; we are interested only in knowing whether, among couples, marriage has a different impact than cohabitation on individual wages and the wage gap between partners.

Our research is designed to test the hypothesis that there are wage premiums and penalties of being married rather than cohabiting. Any answers to this question would shed light on monetary compensation in the event of separation. If marriage (versus cohabitation) wage penalties and premiums exist, compensation might be justified only for married couples. If, on the other hand, there are no significant marriage wage penalties and premiums, this would support the idea that it might be unfair to restrict monetary compensation to only those who are married.

Many empirical studies have shown that married men have higher wages than unmarried men because they are married; in other words, there is a wage premium associated with marriage. However, the international literature shows that this premium is quite low once the selection effect of marriage is taken into account (see, for example, the meta-analysis of Linde Leonard \& Stanley, 2015). A few empirical studies have focused on married women, and their findings are more controversial; they sometimes point to a marriage penalty, but the controversy comes from the fact that it is difficult to separate the effect of marriage from the effect of fertility (Ponthieux \& Meurs, 2015). However, until the beginning of the 2000s, most empirical work was based on a comparison of married and single people, regardless of whether or not they lived in a couple ${ }^{3}$. Few studies specifically considered individuals living in a couple without being married. This results in there being in the literature few articles comparing the economic outcomes of married and unmarried couples.

Our analysis uses data from a French retrospective survey called "Families and Employers" ("Familles et Employeurs"), conducted in 2004-2005. This information is unique in that the survey asks about not only the current wages, employment and family environment, but also the work histories and marital histories of both partners in a large sample of married and unmarried couples ${ }^{4}$ (5,124 individuals in relationships were interviewed). First, relative to previous studies, this paper originally focuses only on couples. In this way we avoid the selection issue of being in a relationship: people not in a relationship might have unobserved characteristics that simultaneously explain their wages and their probability of forming a union. However, we correct for possible selection into marriage relative to cohabitation. Second, we use data on a country in which - relative to other countries - cohabiting and married unions are very similar and a weak socioeconomic gradient exists regarding the choice of marital unions. In a comparative perspective that considers a typology of different forms of cohabitation ${ }^{5}$, France is classified as a country where cohabitation may be considered as an alternative to marriage (Sobotka \& Toulemon, 2008; Heuveline \& Timberlake, 2004). It is even viewed as indistinguishable from marriage in more recent works (Prioux, 2009). Thanks to the similarity and frequency of both marital statuses in France, we are able to analyze to what extent marriage relative to cohabitation affects not only both male and female hourly wages at the individual level, but also the within-couple wage gap.

\footnotetext{
3 Before the 2000s, most of the research was conducted on data from the United States, at a time when cohabitation was still underdeveloped in this country.

${ }^{4}$ Couples having chosen a civil partnership (PACS) are unfortunately not distinguished in the survey. They are thus included in unmarried couples.

${ }^{5}$ Heuveline \& Timberlake (2004) classify countries according to the type of cohabitation defined: 1 ) a marginal phenomenon; 2) a prelude to marriage; 3) an alternative to being single; 4) a stage in the marriage process; 5) an alternative to marriage; or 6) indistinguishable from marriage.
} 
Of course, married and unmarried couples still differ in a number of observed and unobserved characteristics that we are going to take into account ${ }^{6}$. Once controlled for selection into marriage, we show that marital status does not affect hourly wages. The marriage premium relative to cohabiting observed for men is entirely due to selection. We reached the same conclusion for the difference in wage rates within the couple. We have also highlighted that specialization during the lifetime of a couple is a decisive factor in explaining the gender wage gap, as this specialization has a significant and large impact on women's hourly wages.

\section{Wage premiums and penalties associated with being in a relationship, by type of union}

Most research on the relationship between wages and marital status uses mainly legal status to classify individuals into three categories (married, divorced and never married) or five (married, divorced, separated, widowed and never married), with the "never married" category serving as a reference group. Results are sensitive to the number of categories chosen, as pointed out by Shoeni (1995) ${ }^{7}$. However, even if legal status is detailed, that alone does not suffice to characterize different forms of couples.

More recent studies strive to distinguish between the effects of marriage and the effects of living in a partnership by comparing, respectively, married and unmarried individuals to individuals who are living alone and have never been married. The central hypothesis is that cohabitation is associated with smaller wage premiums for men and smaller wage penalties for women when compared with marriage. Many supposed attributes of cohabitation are cited to account for this difference: cohabitation is a less stable form of union (Osborne et al., 2007; Vanderschelden, 2006); cohabiting couples are less likely to have children (Poortmann \& Mills, 2012; Perelli-Harris, 2014); cohabitation entails few legal responsibilities (Perelli-Harris \& Gassen, 2012); cohabiting partners demand less of each other and hence their relationships are more egalitarian, for example in the sharing of domestic work (South \& Spitze, 1994; Barg \& Beblo, 2012; Dominguez-Folgueras, 2012; Bianchi et al., 2014; Kandil \& Périvier, 2017); they have fewer tax advantages (Kabatek et al., 2014); a cohabiting partner has less protection in the event of separation (alimony, sharing of common wealth, etc.) or of the death of the other (survivor pension; Bonnet \& Hourriez, 2012); they pool their resources less (Heimdal \& Houseknecht, 2003; Hamplová \& Le Bourdais, 2009; Ponthieux, 2012; Hamplová et al., 2014); cohabiting couples are less satisfied with their relationships; (Aarskaug et al., 2012) and they have a lower degree of well-being (Soon \& Kalmijn, 2009). All these factors are thought to lead to a less pronounced division of labor (Winkler, 1997; Baxter, 2005; El Lahga \& Moreau, 2007). It should be noted that these studies on premiums and penalties use individuals who have never been married and live alone as the reference group for comparison to others - namely, those who are married, cohabiting or divorced. Hence, the question of a direct, statistically tested ${ }^{8}$ comparison between individuals in married couples and those

\footnotetext{
${ }^{6}$ Prioux (2009) highlights that some covariates still influence the probability of being married compared to cohabiting. It may be a negative influence in the case of women having experienced the separation of their parents or of men who are substantially older), or it may be positive (for both men and women who have religious attachments). Having a diploma plays a weak role, confirming that cohabitation extends to all socioeconomic groups.

7 Regarding men, Shoeni (1995) shows that when five categories are specified (married, divorced, separated, widower, never married), a significant increase occurs in the value of the coefficient associated with the variable "married" in comparison to specifications that cover only two categories (i.e., married versus unmarried).

8 Studies sometimes compare the regression coefficient values without testing for the significance of the differences.
} 
living in unmarried couples is never explicitly broached, with the single exception of Bardasi and Taylor (2008).

In the literature that takes into account the status of cohabitation, several studies find that a male wage premium associated with co-resident partnership exists, but after allowing for the selection effect ${ }^{9}$ (Table 1) it is smaller for unmarried men than for those who are married. Many works find a higher marriage premium than a cohabitating premium for men. This is the case for the first fixed-effects estimate made on US data from Loh (1996). Datta Gupta \& Smith (2002) use random effect estimation to also find a smaller wage premium for cohabiting men in Denmark ${ }^{10}$. Datta Gupta et al. (2007) confirm a slightly lower premium for cohabiting men than for married ones after taking into account the length of time spent in a couple. The study of Dougherty (2006) on US data implies that cohabitation has less impact on wages than marriage. For Germany, Pollmann-Schult (2011) uses a fixed-effects model to also estimate a smaller premium for cohabiting, but it is significant only under a specification that takes into account domestic activity. Similarly, Mamun (2012) finds in the United States that the cohabitation premium is smaller than the marriage premium, but the significance of the coefficients depends on the specification. Using data from the United States, Killewald \& Gough (2013) find that men's wage premium for cohabitation is lower than their wage premium for marriage, and the difference is reinforced by fatherhood. Finally, Budig \& Lim (2016) find a higher premium for married men in the US compared to cohabiting men. They also show that this marriage premium increased in the early 2000s in the US, but that the difference from the cohabitation premium remained approximately the same ${ }^{11}$.

Some works do not even find a premium for cohabiters, whatever the specification. Using a fixed-effects regression, Stratton (2002) finds that, in the United States, cohabitation - that is, the status itself or its duration - is not associated with a statistically significant male wage premium. Using analysis based on propensity score matching, Barg \& Beblo (2009) show that, in Germany, the apparent male wage premium for cohabitation (which is smaller than the marriage premium) is the result of a selection effect similar to that associated with marriage. The estimations of Bardasi \& Taylor (2008) on British data are more ambiguous, since they find a similar wage premium associated with cohabitation and marriage when the domestic work of the spouse is taken into account. In a specification restricted to married and cohabiting men, they also show that there is no statistically significant wage premium for cohabitation (compared to marriage). Thus, it seems that the wage premium for cohabiters is often weaker for unmarried partners relative to married ones, but the results overall are dependent on which characteristics are controlled for and on the characteristics of the country's cohabiters (level of marital specialization, past marital history).

\footnotetext{
${ }^{9}$ The selection effect derives from the fact that wage inequalities between married and unmarried people can result from unobserved characteristics that explain both the probability of being married and the probability of having a high level of human capital (for men) or a low level of human capital (for women), along with the corresponding wage levels. This bias can be corrected, notably by applying fixed effects regressions to longitudinal data. The first articles, which took into account cohabitation but did not correct for selection bias, estimated higher premiums for married men (Schoeni, 1995; Cohen, 2002). The most recent work (Volker \& Brüderl, 2018) uses fixed effects models that correct not only the time-constant unobserved heterogeneity (selection on wage rate level) but also the time-varying unobserved heterogeneity (selection on wage rate growth); they show that the marriage premium for men is entirely due to selection effects.

${ }^{10}$ Nevertheless, they find no more significant effects with a fixed-effects regression. The authors, however, prefer the random effects estimation because of the small number of transitions to cohabitation.

${ }^{11}$ The increase in men's marriage premiums is also shown by the meta-analysis of Linde Leonard \& Stanley (2015).
} 
Table 1: Wage premiums/penalties (coefficients) associated with marriage and cohabitation in (log) wage rate equation, literature review

\begin{tabular}{|c|c|c|c|c|c|c|c|}
\hline & & & & Men & & omen & Remarks \\
\hline Authors & Country & Method & Marriage & Cohabitation & Marriage & Cohabitation & \\
\hline Loh (1996) & & $\mathrm{FE}$ & $0.18^{* *}$ & 0.11 & & & \\
\hline Cohen (2002) & & OLS & $\begin{array}{l}0.214 * * * \\
0.189 * * *\end{array}$ & $\begin{array}{c}0.069 * * * \\
0.032\end{array}$ & & & $\begin{array}{l}\text { White men } \\
\text { Black men }\end{array}$ \\
\hline Stratton (2002) & & $\mathrm{FE}$ & $\begin{array}{l}0.115 \\
0.029\end{array}$ & $\begin{array}{l}-0.027 \\
-0.042\end{array}$ & & & $\begin{array}{l}\text { Specification without duration } \\
\text { Specification with duration (marriage, cohabitation) }\end{array}$ \\
\hline Mamun (2012) & USA & $\mathrm{FE}$ & $\begin{array}{c}0.061^{* *} \\
0.033\end{array}$ & $\begin{array}{c}0.036 \\
0.014 \\
0.088^{*} \\
-0.005 \\
0.069\end{array}$ & & & $\begin{array}{l}\text { Specification without duration } \\
\text { Specification with duration (marriage, cohabitation) } \\
\text { Cohabitation ending in a marriage (specification with duration) } \\
\text { Cohabitation ending in a separation (specification with duration) } \\
\text { Continuation of cohabitation (specification with duration) }\end{array}$ \\
\hline $\begin{array}{l}\text { Killewald } \\
(2012)\end{array}$ & & $\mathrm{FE}$ & $\begin{array}{l}0.073 * * * \\
0.110 * * *\end{array}$ & $\begin{array}{l}0.054 * * * \\
0.052 * * *\end{array}$ & & & $\begin{array}{l}\text { Childless } \\
\text { With child(ren); residential father }\end{array}$ \\
\hline $\begin{array}{l}\text { Killewald, } \\
\text { Gough (2013) }\end{array}$ & & $\mathrm{FE}$ & $\begin{array}{c}0.074 * * * \\
0.092 \# \\
0.122 \#\end{array}$ & $\begin{array}{c}0.063^{* * *} \\
0.065 \# \\
0.022 \#\end{array}$ & $\begin{array}{l}0.039 * * \\
-0.024 \# \\
-0.114 \#\end{array}$ & $\begin{array}{c}0.031 * \\
0.020 \# \\
-0.090 \#\end{array}$ & $\begin{array}{l}\text { Childless } \\
\text { One child (ref. never married, childless) } \\
\text { Two children or more (ref. never married, childless) }\end{array}$ \\
\hline $\begin{array}{l}\text { Budig, Lim } \\
(2016)\end{array}$ & & FE & $\begin{array}{l}0.067 * * * \\
0.102 * * *\end{array}$ & $\begin{array}{l}0.036 * * * \\
0.055^{* * *}\end{array}$ & $\begin{array}{c}-0.001 \\
0.015\end{array}$ & $\begin{array}{l}0.005 \\
0.023\end{array}$ & $\begin{array}{l}1979-1989 \\
1997-2010 \\
\end{array}$ \\
\hline $\begin{array}{l}\text { Datta Gupta, } \\
\text { Smith (2002) }\end{array}$ & & $\begin{array}{l}\mathrm{FE} \\
\mathrm{RE}\end{array}$ & $\begin{array}{c}0.024^{*} \\
0.005\end{array}$ & $\begin{array}{c}0.013^{*} \\
0.000\end{array}$ & $\begin{array}{l}-0.005 \\
0.000 \\
\end{array}$ & $\begin{array}{l}0.010 \\
0.007\end{array}$ & \\
\hline $\begin{array}{l}\text { Datta Gupta et } \\
\text { al. (2007) }\end{array}$ & Denmark & $\mathrm{FE}$ & $\begin{array}{l}0.016 * * * \\
0.012 * * * \\
0.016 * * *\end{array}$ & $\begin{array}{l}0,014 * * * \\
0.009 * * * \\
0.016 * * *\end{array}$ & & & $\begin{array}{l}\text { Lifetime in couple taken into account, all men } \\
\text { Lifetime in couple not taken into account, only full time } \\
\text { employees } \\
\text { Lifetime in couple not taken into account, all men }\end{array}$ \\
\hline Schoeni (1995) & & OLS & $0.251 * * *$ & 0.056 & & & \\
\hline $\begin{array}{l}\text { Pollmann- } \\
\text { Schult (2011) }\end{array}$ & Germany & $\mathrm{FE}$ & $0.041^{* *}$ & 0.014 & & & $\begin{array}{l}\text { Specification without information on the activity of the spouse } \\
\text { and the domestic activity of the man } \\
\text { Specification with information on the activity of the spouse and } \\
\text { the domestic activity of the man }\end{array}$ \\
\hline $\begin{array}{l}\text { Bardasi, Taylor } \\
(2008)\end{array}$ & $\begin{array}{l}\text { Great- } \\
\text { Britain }\end{array}$ & $\mathrm{FE}$ & $\begin{array}{c}0.05 * * \\
0.03\end{array}$ & $\begin{array}{c}0.04 * * \\
0.02\end{array}$ & & & $\begin{array}{l}\text { Specification without the number of domestic chores for } \\
\text { which woman is responsible } \\
\text { Specification with the number of domestic chores for } \\
\text { which woman is responsible }\end{array}$ \\
\hline
\end{tabular}

FE: Fixed Effect. RE: Random Effect. OLS: Ordinary Least Squares. ${ }^{*} p<.05 ;{ }^{* *} p<.01 ;{ }^{* *} p<.001 . \# p$ value not known. 
Regarding the impact of marriage or cohabitation on women's wages and the presence of a wage penalty such as those generally observed for married women, the results are mixed. Datta Gupta \& Smith (2002) use both fixed-effects and random-effects models on Danish data to find that neither has a significant impact. Killewald \& Gough (2013) find that American mothers have similar wage penalties whether they are married or cohabiting, but they observe significant wage premiums for marriage and for cohabitation among childless women (with slightly larger premiums for marriage). Light (2004) shows that, ceteris paribus, the transition to marriage or to cohabitation in the United States has the same positive impact on women's total income and standard of living when the selection effect is taken into account. Avellar \& Smock (2005) show that married women's and unmarried women's median incomes are not significantly different, whether incomes are observed before or after a couple separates. Dougherty (2006) finds no impact of living in a partnership (married or unmarried) on women's wages, but marriage is associated with a wage premium (significant with a fixed-effects regression), a result that implies that if a wage premium linked to cohabitation exists, it is weakly significant. Finally, Budig \& Lim (2016) show with US data and a fixed-effects model that the penalties for women are not significantly different from zero, whether it is marriage or cohabitation and whatever the observation period between 1979 and 2010 that is considered by the authors.

Several mechanisms may drive the wage premiums and penalties. Discrimination by marital status is one of them. The conclusions of some studies find positive discrimination by employers toward wageearning men who are married (Pollmann-Schultz, 2011; Hundley, 2000), which is based on the result that the marriage premium is not observed among the self-employed. The conclusions of other studies find an absence of such discrimination (Petersen et al., 2011; Loh, 1996; Jacobsen \& Rayack, 1996). Regarding married women (or mothers), a part of the wage penalty may also result from their more inelastic labor supply, which is linked to their family obligations. As these women are less (or not at all) geographically mobile or because they need to work closer to home in order to meet their domestic responsibilities, employers may pay them below the competitive wage (Ponthieux \& Meurs, 2015). But no papers focus specifically on the possible discrimination between married and cohabiting individuals. Another important mechanism might come from the division of labor within couples. Researchers who study wage premiums and penalties attempt to improve specifications for the division of labor within couples by using different indicators. They take the partner's employment or non-employment into account. Usually, this question is investigated using wage equations for men, based on the hypothesis that the woman's paid employment should reduce the man's wage because roles within the couple are less specialized. In studies that focus on cohabitation as well as marriage, this hypothesis is verified ${ }^{12}$. It should be noted that none of these studies investigate any possible differences according to the type of couple (married, cohabiting), with the exception of Mamun (2012), who estimates the effect of the interaction between marital status and the education level of the employed spouse. The author shows that the expected negative effect of the spouse's activity (a variable specified by education levels) is significant only in its interaction with marriage and not with cohabitation. Domestic work is also an indicator of specialization used in this type of estimation, but there are few works that take into account cohabitation and include a domestic work variable. In his estimate of the German male wage equation, Pollmann-Schult (2011) integrates the domestic work time of the man (according to three categories)

\footnotetext{
12 In the literature that takes into account the status of cohabitation, the hypothesis is verified in: Bardasi \& Taylor (2008), who use the number of hours of work (the effect is reinforced when the authors take endogeneity into account by using an instrumental variable); and in Pollman-Schult (2011), Killewald (2013) and Killewald \& Gough (2013), who use the classification "employed part-time or full-time versus non-employed". Killewald \& Gough (2013) study the same hypothesis for women; their estimation shows a non-significant effect, a result that is not surprising given that the vast majority of men work full time.
} 
and finds that its impact is not significant. Bardasi \& Taylor (2008) include in their estimate of the British male wage rate an indicator of the number of domestic activities performed by the spouse; the expected positive impact is actually estimated as positive and significant (the male wage rate would increase by $1.4 \%$ for each task supported by the spouse). Researchers also study the effect of the duration of marriage or cohabitation, based on the idea that the impact of specialization should grow over time because losses or gains in human capital due to specialization accrue over time. Applying this approach to the United States, Stratton (2002) \& Mamun (2012) reach a similar conclusion: the duration of marriage has a significant positive effect on male wages; the duration of cohabitation has no significant effect. In contrast, for Denmark, Datta Gupta et al. (2007) find that a couple's duration has a significant negative effect on male wages, whether the couple is married or unmarried ${ }^{13}$.

All in all, the empirical literature is rather controversial. Marriage and cohabitation are very rarely compared directly (except in Bardasi \& Taylor, 2008), since individuals living together are systematically compared to individuals living alone. Furthermore, as far as we know, no studies deal with the situation in France, a country where different types of couples have been common for a long time.

\section{Data and descriptive statistics: Wage premiums and a couple's status}

To analyze the link between marital status and wages, we use the INED "Families and Employers" survey carried out in 2004-2005. This information about respondents aged 20 to 49 is unique, since information about wages, employment, family environment, work histories and marital histories are available for a large sample of married and unmarried partners. We selected a sample containing people in a coresident relationship at the time of the survey (singles are excluded): 2,749 women among, of whom 2,275 are wage earners ${ }^{14}$; and 2,375 wage-earning men. In our sample, $70 \%$ of the women and $69 \%$ of the men were married. To qualify the remaining non-married couples in this article, the terms "unmarried" and "cohabiting" will be used interchangeably. To study the wage gap within couples (defined as the man's wage minus the woman's wage) depending on the type of union, we also build a reduced sample of couples $(N=1,602)$ that includes the two members of the couple who each filled in the retrospective calendar.

Table 2 shows that men's hourly wages are always higher than women's, on average and for all the quartiles (first, second and third). The difference between individuals in married and unmarried couples is small with the expected sign: at the mean or at each quartile, the hourly wage is slightly and significantly higher for married men than for cohabiting men. For women, the difference is never significant (except for the third quartile) and does not conform to the hypothesis of a smaller wage penalty for cohabiting women compared to married ones. Regression models will use the logarithm of hourly wage presented in the first line of Table 3.

\footnotetext{
${ }^{13}$ We do not know of any studies that use the duration of cohabitation as a determinant of women's wages.

${ }^{14}$ We included in the estimation 474 women who were not employed in order to control for self-selection into the labor market, but excluded 79 women who were self-employed ( $82 \%$ of the women in the overall sample were wage earners) and 78 men ( $97 \%$ of the men in the overall sample were wage earners).
} 
Table 2: Hourly wage of men and women, by marital status

\begin{tabular}{|c|c|c|c|c|c|c|}
\hline & \multicolumn{3}{|c|}{ Women } & \multicolumn{3}{|c|}{ Men } \\
\hline & Married & Cohabitant & Different? & Married & Cohabitant & Different? \\
\hline \multicolumn{7}{|l|}{ Hourly wage (euros) } \\
\hline Mean & 9.472 & 9.079 & No & 11.905 & 9.972 & Yes $* * *$ \\
\hline Standard deviation & 6.309 & 4.247 & & 8.585 & 5.576 & \\
\hline $1^{\text {st }}$ quartile & 6.590 & 6.593 & No & 7.9125 & 7.219 & Yes $* * *$ \\
\hline Median & 8.182 & 7.933 & No & 9.8905 & 8.545 & Yes $* * *$ \\
\hline $3^{\text {rd }}$ quartile & 10.728 & 10.096 & Yes ** & 13.2695 & 11.032 & Yes $* * *$ \\
\hline $\mathrm{N}$ & 1604 & 671 & & 1635 & 740 & \\
\hline
\end{tabular}

Source: Families and Employers Survey, 2004-2005 (INED)

The third columns of women and men indicate (using OLS and quantile regressions) whether the values are significantly different for married and unmarried. * Significantly different at the $10 \%$ level; ** at the $5 \%$ level; *** at the $1 \%$ level.

However, the raw differences between individuals in different types of couples could be due in part to structural differences (Prioux, 2009). Indeed, the two subgroups of married and cohabiting individuals differ in some characteristics (Table 3). Married couples are twice as likely to have children as cohabiting couples. We observe differences in age between the two groups, specifically differences that also translate into longer work experience and higher job tenure for married individuals, which is in line with their longer couple duration on average. These differences show that married and unmarried couples are not at the same stage in their life cycles. A portion of those who were currently cohabiting would marry later. This applies to both women and men, even though it may be considered that marriage can generate stronger incentives for lower earners (generally women) to withdraw from the labor market in order to fulfill family responsibilities. Similarly, married couples are slightly less likely than cohabiting couples to live in the Paris region. The difference in national origin between married and cohabiting individuals is more marked: Those who are married are more often children of immigrants, a fact that probably stems from cultural differences in attitudes toward marriage.

In contrast, there are few differences between married and cohabiting women in terms of education and current employment. They have the same levels of education; the same proportion in positions of responsibility; and they work in the same sectors as well as in companies of the same size. There is one slight difference: Married women are a little more likely to work in the public sector and to have jobs providing services to private households. Differences between married and cohabiting men are a bit more pronounced. Married men are more likely than cohabiting men to have a low-level technical diploma (CAP) rather than a "baccalauréat" (a two-year academic degree) or a university diploma (a difference that could be due to differences in age and hence generational). Similarly, married men occupy positions of responsibility a little more often than cohabiting men; they also work a little more often in the public sector and less often at providing services to private households than do cohabiting men. Finally, differences are not very pronounced in regard to the type of couple in terms of their professional situations: $74 \%$ of married men and $77 \%$ of cohabiting men live with a woman who is employed; $94 \%$ of married women and $92 \%$ of cohabiting women live with a man who is employed. 
Table 3: Averages for characteristics of population subgroups

\begin{tabular}{|c|c|c|c|c|c|c|c|c|}
\hline \multirow[b]{3}{*}{ variable } & \multicolumn{4}{|c|}{ Women } & \multicolumn{4}{|c|}{ Men } \\
\hline & \multicolumn{2}{|c|}{ Married } & \multicolumn{2}{|c|}{ Cohabiting } & \multicolumn{2}{|c|}{ Married } & \multicolumn{2}{|c|}{ Cohabiting } \\
\hline & mean & $s d$ & mean & $s d$ & Mean & $s d$ & mean & $s d$ \\
\hline Log of hourly wage & 2.14 & 0.43 & 2.13 & 0.37 & 2.37 & 0.42 & 2.22 & 0.37 \\
\hline Age & 38.68 & 6.71 & 32.90 & 7.48 & 39.03 & 6.44 & 33.94 & 7.20 \\
\hline Childless & 0.09 & 0.29 & 0.39 & 0.49 & 0.09 & 0.29 & 0.42 & 0.49 \\
\hline 1 child & 0.21 & 0.41 & 0.31 & 0.46 & 0.21 & 0.41 & 0.26 & 0.44 \\
\hline 2 children & 0.47 & 0.50 & 0.23 & 0.42 & 0.45 & 0.50 & 0.24 & 0.43 \\
\hline 3 or more children & 0.22 & 0.42 & 0.07 & 0.26 & 0.25 & 0.43 & 0.09 & 0.29 \\
\hline Second union & 0.11 & 0.31 & 0.30 & 0.46 & 0.13 & 0.34 & 0.31 & 0.46 \\
\hline Non-native & 0.08 & 0.27 & 0.03 & 0.18 & 0.09 & 0.29 & 0.04 & 0.19 \\
\hline Paris and suburbs & 0.17 & 0.38 & 0.20 & 0.40 & 0.17 & 0.37 & 0.20 & 0.40 \\
\hline University 3rd cycle & 0.09 & 0.28 & 0.09 & 0.29 & 0.10 & 0.29 & 0.10 & 0.30 \\
\hline University 2 nd cycle & 0.13 & 0.33 & 0.15 & 0.36 & 0.08 & 0.28 & 0.08 & 0.26 \\
\hline University 1st cycle & 0.15 & 0.36 & 0.17 & 0.37 & 0.10 & 0.30 & 0.12 & 0.33 \\
\hline Baccalauréat & 0.18 & 0.39 & 0.22 & 0.41 & 0.14 & 0.35 & 0.18 & 0.38 \\
\hline CAP diploma & 0.25 & 0.43 & 0.23 & 0.42 & 0.38 & 0.49 & 0.32 & 0.47 \\
\hline Brevet diploma & 0.07 & 0.25 & 0.05 & 0.22 & 0.07 & 0.25 & 0.08 & 0.27 \\
\hline Real experience & 15.65 & 7.84 & 11.09 & 7.78 & 18.33 & 7.43 & 12.90 & 7.89 \\
\hline Square of real experience & 306.41 & 256.35 & 183.10 & 216.28 & 391.16 & 265.84 & 228.51 & 233.97 \\
\hline Health problems during lifetime & 0.13 & 0.34 & 0.10 & 0.29 & 0.13 & 0.33 & 0.11 & 0.31 \\
\hline Tenure & 10.08 & 8.18 & 6.51 & 6.73 & 11.19 & 8.39 & 6.96 & 6.81 \\
\hline Position with responsibilities & 0.17 & 0.37 & 0.17 & 0.38 & 0.39 & 0.49 & 0.31 & 0.46 \\
\hline Public sector & 0.33 & 0.47 & 0.29 & 0.45 & 0.23 & 0.42 & 0.21 & 0.41 \\
\hline Industrial \& construction & 0.16 & 0.36 & 0.15 & 0.36 & 0.40 & 0.49 & 0.39 & 0.49 \\
\hline Finance, services for companies & 0.14 & 0.35 & 0.15 & 0.35 & 0.20 & 0.40 & 0.18 & 0.39 \\
\hline $\begin{array}{l}\text { Real estate, trade, services for } \\
\text { household }\end{array}$ & 0.26 & 0.44 & 0.31 & 0.464 & 0.17 & 0.38 & 0.20 & 0.40 \\
\hline Education \& health sector & 0.30 & 0.46 & 0.25 & 0.43 & 0.09 & 0.28 & 0.08 & 0.27 \\
\hline$<20$ employees & 0.37 & 0.48 & 0.36 & 0.48 & 0.28 & 0.45 & 0.28 & 0.45 \\
\hline 20-49 employees & 0.14 & 0.35 & 0.15 & 0.36 & 0.13 & 0.34 & 0.14 & 0.34 \\
\hline 50-50 employees & 0.21 & 0.41 & 0.20 & 0.40 & 0.24 & 0.43 & 0.26 & 0.44 \\
\hline 200-499 employees & 0.12 & 0.33 & 0.13 & 0.34 & 0.14 & 0.35 & 0.13 & 0.33 \\
\hline 500-999 employees & 0.06 & 0.23 & 0.06 & 0.24 & 0.08 & 0.27 & 0.08 & 0.26 \\
\hline Partner employed & 0.94 & 0.24 & 0.92 & 0.27 & 0.74 & 0.44 & 0.77 & 0.42 \\
\hline $\begin{array}{l}\text { Specialization(\% time in } \\
\text { inactivity since couple formation) }\end{array}$ & 0.14 & 0.21 & 0.05 & 0.13 & 0.01 & 0.05 & 0.01 & 0.08 \\
\hline Religion important & 0.29 & 0.45 & 0.14 & 0.35 & 0.22 & 0.41 & 0.09 & 0.29 \\
\hline $\mathrm{N}$ & 1604 & & 671 & & 1635 & & 740 & \\
\hline
\end{tabular}

Source: Families and Employers Survey, 2004-2005 (INED).

\section{Wage premiums and marital status of individuals living in a couple: an econometric approach}

To go further in our analysis of the links between wage premiums (or penalties) and marital status, several methodological problems have to be dealt with. First of all, given that having children may result in women's withdrawal from the labor market, there may be a selection bias. For this reason, we have corrected for this bias by using the Heckman method (two-step estimation), and we introduce an inverse Mills ratio into our regressions. The exclusion variables used are the presence of a child under school age (under 3) and an indicator of the employment of the respondent's mother, since we assume that career patterns may be transmitted from mothers to daughters. Second, we proceed in steps to 
find the determinants of wage rates and their effects on our variable of interest ${ }^{15}$. We first introduce demographic variables (Specification 1). We then add human capital (Specification 2) and employment variables (Specification 3). An alternative specification controlling for couple duration, as done by Mamun (2012), has also been tested. However, this variable may be highly correlated with our variable of interest (marital status) and many covariates (age, experience, number of children), so we do not keep it in the final specification ${ }^{16}$.

Finally, as the literature on wage premiums and penalties associated with marriage explicitly shows, it is essential to take unobserved heterogeneity into account because unobserved characteristics can simultaneously influence wage rates and the decision to marry. To do so, we take an instrumental variable approach (IV, Specification 4) by using the respondent's religiosity as an instrument. It is wellknown that people with religious feelings are more likely to marry. This variable increases the probability of marrying rather than cohabiting. The risk of any weak instrument issues is ruled out by the high value of the F-statistics (the F-statistic for instruments equals 32 for both women and men, 12 for the couple regression) when testing the nullity of the instrument in the first-stage regression. The firststage equations of the IV estimations are provided in Table A4 (Appendix).

We analyze women's wage rates first (Table 4), followed by the men's (Table 5). Then, Table 6 shows results that shed light on the question of the role played by specialization, with an indicator of the partner's absence from the labor market over the lifetime of the couple ${ }^{17}$. Indeed, studies on the relationship between marriage and wages have tested the hypothesis that the impact of marriage is due to specialization within couples. Finally, the last part of the article (Table 7) examines the differences in wage rates within the couple - an original aspect of our work if compared to previous studies. While the gender wage gap is largely studied by comparing men and women in the whole active population, there are still very few studies that analyze the gender wage gap and its main determinants at the couple level. This is an attempt to fully understand the within-couple mechanisms that lead to wage differences, which are hereafter of great importance, particularly in the case of marital dissolution.

\subsection{Women's hourly wages}

Regarding women's wage rates, our results confirm the role of standard variables (diploma, experience, job tenure, residence, sector, size of firm, etc.), and they indicate that selection into employment is weak. The inverse of the Mills ratio is positive but either not significant or only weakly so. A more surprising result is that the presence of children seems to have no effect on women's hourly wage rates: when living in a relationship, having one or more children (for a given level of real employment experience) apparently has no effect on women's wage rates ${ }^{18}$. Additional estimations show that this result is due to two elements. First, we introduced real - rather than potential - employment experience in the regression. This means that it takes into account childbearing interruptions, in particular periods of parental leave or periods of withdrawal from employment that are mainly for family reasons and that are the main drivers of the child or motherhood wage penalty for women ${ }^{19}$.

\footnotetext{
15 The results presented concern the log of the hourly wage rate. We have considered the log of the monthly wage rate (by adding variables that explain work time), but since these results are almost identical to the first set of results, they are not presented here.

${ }^{16}$ Results were not affected when introducing couple duration and are available upon request from the authors.

${ }^{17}$ Specialization also depends on choices regarding domestic work, which are not strictly dependent on choices regarding paid employment, but we have no information on domestic work in the survey.

18 Davies \& Pierre (2005) obtain a similar result.

${ }^{19}$ These results are in line with those obtained by Meurs et al. (2010) on French data.
} 
Second, the number of hours of paid work is used to calculate the hourly wage rate (hence, allowing for possible transitions to a part-time schedule for family reasons).

This analysis shows that, for women, there is no significant wage penalty for marriage (compared to cohabitation). Married women's hourly wage rates are equal to those of cohabiting women given basic demographic controls (Specification 1) and human capital controls (Specification 2). A weak penalty is visible in Specification 3 (with employment characteristics). Thus, women's wage penalty for marriage (as opposed to cohabitation) due to marital status itself does not exist or is very weak. This non-effect of being married is confirmed after correcting for the possible endogeneity of marriage. Married women may indeed have unobserved characteristics that explain both the probability of getting married and the probability of having low hourly wages (Instrumental Variable Specification 4).

Table 4: Estimation of the Log of hourly wage rate for women

\begin{tabular}{lcrrr}
\hline & \multicolumn{1}{c}{$(1)$} & $(2)$ & \multicolumn{1}{c}{$(3)$} & $(4)$ \\
& OLS & \multicolumn{1}{c}{ OLS } & \multicolumn{1}{c}{ OLS } & \multicolumn{1}{c}{ IV } \\
\hline Married & -0.001 & -0.024 & $-0.029^{*}$ & -0.071 \\
& $(0.020)$ & $(0.017)$ & $(0.017)$ & $(0.111)$ \\
Inverse Mill's ratio & 0.144 & $0.160^{* *}$ & 0.108 & 0.109 \\
& $(0.175)$ & $(0.080)$ & $(0.078)$ & $(0.078)$ \\
Constant & $1.800^{* * *}$ & $1.645^{* * *}$ & $1.686^{* * *}$ & $1.685^{* * *}$ \\
& $(0.048)$ & $(0.069)$ & $(0.080)$ & $(0.080)$ \\
\hline Demographic variables & $\mathrm{X}$ & $\mathrm{X}$ & $\mathrm{X}$ & $\mathrm{X}$ \\
Human capital & & $\mathrm{X}$ & $\mathrm{X}$ & $\mathrm{X}$ \\
Employment characteristics & & & $\mathrm{X}$ & $\mathrm{X}$ \\
\hline $\mathrm{R}^{2}$ & 0.05 & 0.32 & 0.39 & 0.39 \\
$\mathrm{~N}$ & 2,275 & 2,275 & 2,275 & 2,275 \\
\hline
\end{tabular}

Source: Families and Employers Survey, 2004-2005 (INED). * Significant at the 10\% level; ** significant at the 5\% level; ***significant at the $1 \%$ level.

Other covariates (cf. Appendix Table A1). Demographic variables include: age, number of children, rank of the union, immigrant, living in Paris region. Human capital variables include: education, experience and square, health problems during lifetime. Employment variables include job tenure, managerial responsibilities, sector, firm size (number of employees)

\subsection{Men's hourly wage}

The results for men are different (Table 5 and Table A2 in Appendix). Like many studies on marriage wage premiums, we find a positive impact of marriage on men's wages in Specifications 1, 2 and 3, pointing to a wage premium for marriage (as compared to cohabitation) of around 7 per cent. However, when we take into account the unobservable characteristics of married men compared to cohabiting men, the coefficient associated with marriage is no longer significant (IV specification). Hence, men's wage premium for marriage appears to be due to unobserved characteristics (that are also associated with higher wages). This leads to the idea that married men have traits that make them more attractive on the marriage market and on the labor market. Once this phenomenon has been taken into account, the wage premium for marriage (compared to cohabitation) is no longer observed. 
Table 5: Estimation of the log of hourly wage rate for men

\begin{tabular}{|c|c|c|c|c|}
\hline & (1) & $(2)$ & (3) & (4) \\
\hline & OLS & OLS & OLS & IV \\
\hline \multirow[t]{2}{*}{ Married } & $0.113^{* * *}$ & $0.075^{* * *}$ & $0.071 * * *$ & -0.131 \\
\hline & $(0.018)$ & $(0.016)$ & $(0.015)$ & $(0.121)$ \\
\hline \multirow[t]{2}{*}{ Constant } & $1.822^{* * *}$ & $1.510 * * *$ & $1.559 * * *$ & $1.576 * * *$ \\
\hline & $(0.043)$ & $(0.102)$ & $(0.117)$ & $(0.115)$ \\
\hline Demographic variables & $\mathrm{x}$ & $x$ & $x$ & $\mathrm{x}$ \\
\hline Human capital & & $x$ & $x$ & $x$ \\
\hline Employment characteristics & & & $\mathrm{x}$ & $\mathrm{x}$ \\
\hline $\mathrm{R}^{2}$ & 0.13 & 0.37 & 0.42 & 0.38 \\
\hline Sample size & 2,375 & 2,375 & 2,375 & 2,375 \\
\hline \multicolumn{5}{|c|}{$\begin{array}{l}\text { Other covariates (cf. Appendix Table A2). Demographic variables include: age, number of children, rank of the } \\
\text { union, immigrant, living in Paris region. Human capital variables include: education, experience and square, health } \\
\text { problems during lifetime. Employment variables include job tenure, managerial responsibilities, sector, firm size } \\
\text { (number of employees). }\end{array}$} \\
\hline
\end{tabular}

\subsection{The role of specialization}

We now focus on one possible mechanism of gender wage inequalities, which is marital specialization. We use two indicators: the partner's current employment status and an indicator of specialization process, computed as the proportion of inactive years (years out of the labor market) over the current couple's life course. Note that these indicators could have different meanings for women and men. As the activity status is more heterogeneous for women than for men, the partner's status is expected to have more effect on men's wages than on women's wages. Because inactivity periods are more likely to be related to family reasons and involve a higher investment in domestic and parental tasks for women than for men, we also expect more effect on women's wages than on men's. For men, the reasons for career breaks (excluding unemployment periods) are generally more related to health issues. However, for purpose of comparison, we kept the two indicators in each regression.

Our analyses show that marital status does not affect the wage rates of women living in a partnership, once we control for these two specialization indicators. The specifications OLS and IV show significantly that the longer the woman is inactive during the partnership (greater specialization of the couple), the lower her wage rate is (around $3 \%$ when the women are inactive for $10 \%$ of the time since the couple's formation). The fact that the man is currently working does not have a significant impact.

The analysis of men's wages also provides interesting results. First, they confirm previous findings: a positive effect of marriage under the OLS specification, and no longer significant under the IV specification. But unlike the analysis for women, the women's current activity status affects negatively and significantly (because it measures less specialization in the couple), as it reduces the hourly wage rate by $3 \%$. On the other hand, the indicator of male inactivity over the couple's life course has a negative effect on wages, but of a smaller magnitude compared to women. This is in line with the specialization issue: the higher level of investment in the domestic sphere diminishes the wage gains, but this assumption is much less likely for men. As previously mentioned, the negative sign may also suggest a health issue. 
Table 6: The role of specialization on wages

\begin{tabular}{lcccc}
\hline & \multicolumn{2}{c}{ Women } & \multicolumn{2}{c}{ Men } \\
& OLS & IV & OLS & IV \\
\hline Married & -0.023 & -0.028 & $0.070^{* * *}$ & -0.143 \\
& $(0.017)$ & $(0.104)$ & $(0.015)$ & $(0.123)$ \\
Working partner & -0.046 & -0.045 & $-0.028^{*}$ & $-0.030^{*}$ \\
& $(0.033)$ & $(0.033)$ & $(0.017)$ & $(0.018)$ \\
Respondent specialization (\%) & $-0.298^{* * *}$ & $-0.296^{* * *}$ & $-0.173^{*}$ & $-0.181^{*}$ \\
& $(0.103)$ & $(0.112)$ & $(0.099)$ & $(0.103)$ \\
Inverse Mill's ratio & $0.141^{*}$ & $0.140^{*}$ & & \\
& $(0.084)$ & $(0.085)$ & & $1.589 * * *$ \\
Constant & $1.624^{* * *}$ & $1.625^{* * *}$ & $1.570^{* * *}$ & $(0.116)$ \\
$R^{2}$ & $(0.086)$ & $(0.086)$ & $(0.118)$ & 0.38 \\
$N$ & 0.39 & 0.39 & 0.42 & 2,375 \\
\hline Source: Families and Employers Survey, 2004-2005 (INED). * Significant at the 10\% level; **significant at the 5\%
\end{tabular}

\section{The wage gap between partners}

After this analysis on individual wage by gender, we look at the wage gap between partners, a question not addressed by other studies from the perspective of union status (married or cohabiting). This investigation is made possible by our data that provides information on wages for both members of couples. This question is important. For instance, the justification of monetary compensation upon divorce, a right reserved to married couples as pointed out previously, is based on inequalities in standard of living (of which wages are a key determinant) and/or on compensation for a higher investment in unpaid domestic work (and hence an at least partial withdrawal from the labor market), which influences the wage level.

The literature on the gender wage gap (comparing men's and women's average wages) is very abundant (Altonji \& Blank, 1999, Ponthieux \& Meurs, 2015), but the literature dealing more specifically with the intra-couple gender wage gap is much rarer. Some studies focus on wage homogamy (Frémeaux \& Lefranc, 2017; Hu \& Qia, 2015) and some others mobilize the intra-couple gender wage gap as a determinant of other outcomes such as the probability of divorce (Brines \& Joyner, 1999; Bertrand et al., 2015), the allocation of domestic tasks (Ponthieux \& Schreiber, 2006; Bloemen \& Stancanelli, 2014; Sofer \& Thibout, 2015; Bertrand et al., 2015) and the inequality of inter-household income (Blau, 1998; Schwartz 2010, Frémeaux \& Lefranc 2017). We are not aware of any work studying intra-couple wage inequality according to the type of union (marriage versus cohabitation). However, we can report some results close to our research question. Morin (2014) shows that, in France, the contribution of women to the couple's activity or replacement incomes is lower among married couples than among cohabiting couples: $34 \%$ versus $41 \%$. Ravazzini et al. (2017), based on Swiss data, estimate a negative effect of couple duration on the ratio of intra-couple wage rates, but the authors do not distinguish the effect according to the type of couple. Bloemen \& Stancanelli (2015) show that cohabiting couples in France are more likely than married couples to live in households where the woman is the sole provider of income, and they are less likely to live in a dual-income household where the woman earns more than the man. 
Descriptive statistics are reported in Table 7. In $30 \%$ of the dual-earner couples in our sample, the woman earns more than her partner ${ }^{20}$. We also observe that the wage difference within the couple is larger among married couples than cohabiting couples. This is true at the mean as well as along the distribution, at the median and at the third quartile. We observed no difference between marital status at the bottom of the distribution (first quartile) for couples in which the woman's wage is higher than the man's (the difference is negative).

Table 7: Hourly wage gap within couple by marital status (in euros)

\begin{tabular}{|l|c|c|c|}
\hline & \multicolumn{3}{|c|}{ Couple } \\
\hline & Married & Cohabiting & Different? \\
\hline Mean & $\mathbf{2 . 3 3}$ & $\mathbf{1 . 3 9}$ & Yes* \\
\hline $1^{\text {st }}$ quartile & -0.39 & -0.58 & No \\
\hline Median & 1.74 & 0.82 & Yes *** \\
\hline $3^{\text {rd }}$ quartile & 4.23 & 2.82 & Yes *** \\
\hline Number of obs. & 1090 & 511 & \\
\hline
\end{tabular}

Source: Families and Employers Survey, 2004-2005 (INED).

Note: Hourly wage gap is defined as man's hourly wage minus woman's hourly wage.

The models are presented in Table 8. The wage gap is defined as the man's log of hourly wage minus the woman's log of hourly wage. For parsimonious reasons and given the reduced sample size of couples for which we are able to observe both partners $(n=1,601)$, the models do not include all the previous individual controls for both men and women. Some are grouped into fewer items (education level, number of children, firm size) and some are dropped (firm detailed by sector, but we keep whether the firm belongs to the public or private sector) ${ }^{21}$. Results show symmetrical effects of male and female characteristics on the wage gap: characteristics that increase the man's hourly wage increase the wage gap, and characteristics that increase the woman's hourly wage decrease the wage gap. Thus, for example, the higher men's level of education, the higher their hourly wages; and this widens the wage gap between partners. However, since there is also a positive relationship between women's education and wages: the more educated women are, the smaller the gap between their wages and those of their male partners (a negative effect in this case).

Since the impact of marriage on individual wage differs by sex, it is interesting to observe its overall effect on the wage gap between partners. Our analysis shows that marriage has a positive and significant effect in the OLS specification. The gap in partners' hourly wages confirms previous descriptive statistics and is larger for married couples than for cohabiting couples, a finding we would expect if marriage creates incentives for specialization. The introduction of the marital specialization ${ }^{22}$ index reduces but does not cancel the positive effect of marriage on the wage gap. However, when unobservable characteristics of married couples are taken into account, this effect is no longer significant. Marriage does not seem to enlarge wage inequalities once selection into marriage (versus cohabitation) is taken into account. Unobserved characteristics that are correlated with marriage explain the higher gap found in the OLS estimations. Note that the specialization index remains highly

\footnotetext{
${ }^{20}$ Using the 2002 Labor Force Survey, Bloemen \& Stancanelli (2015) indicate a similar proportion (31\%, p. 511).

${ }^{21}$ Alternative regressions that include additional and detailed variables have been tested, and the results are very robust. Results are available upon request from the authors.

${ }^{22}$ Computation of marital specialization for couples is a bit different than at the individual level. This indicator is computed as the ratio between the difference between the two partner's inactivity durations and the couple's duration.
} 
significant and explains a large part of the wage gap between partners. However, there is no additional effect of marital status.

Table 8: Estimation of the gap between a man's and woman's hourly wage rate (log)

\begin{tabular}{|c|c|c|c|c|c|}
\hline & $\begin{array}{l}\text { OLS } \\
(1)\end{array}$ & $\begin{array}{c}\text { OLS } \\
(2)\end{array}$ & $\begin{array}{l}\text { OLS } \\
\text { (3) }\end{array}$ & $\begin{array}{c}\text { OLS } \\
\text { (4) }\end{array}$ & $\begin{array}{l}\text { IV } \\
\text { (5) }\end{array}$ \\
\hline \multirow[t]{2}{*}{ Married } & $0.071^{* *}$ & $0.071^{* *}$ & $0.072 * * *$ & $0.061 * *$ & 0.042 \\
\hline & $(0.028)$ & $(0.028)$ & $(0.027)$ & $(0.027)$ & $(0.133)$ \\
\hline \multirow[t]{2}{*}{ Couple specialization } & & & & $0.458 * * *$ & $0.478 * * *$ \\
\hline & & & & $(0.126)$ & $(0.142)$ \\
\hline \multirow[t]{2}{*}{ Inverse Mill's ratio } & -0.095 & 0.037 & 0.071 & -0.180 & $-0.198 *$ \\
\hline & (0.224) & $(0.098)$ & $(0.095)$ & $(0.110)$ & $(0.108)$ \\
\hline Constant & $\begin{array}{l}-0.006 \\
(0.065)\end{array}$ & $\begin{array}{l}-0.340^{* *} \\
(0.136)\end{array}$ & $\begin{array}{l}-0.325^{* *} \\
(0.135)\end{array}$ & $\begin{array}{l}-0.287^{* *} \\
(0.130)\end{array}$ & $\begin{array}{l}-0.290^{*} \\
(0.162)\end{array}$ \\
\hline Demographic variables & $x$ & $x$ & $x$ & $x$ & $x$ \\
\hline Human capital & & $x$ & $\mathrm{x}$ & $x$ & $\mathrm{x}$ \\
\hline Employment characteristics & & & $x$ & $x$ & $x$ \\
\hline$R^{2}$ & 0.03 & 0.09 & 0.15 & 0.16 & 0.16 \\
\hline$N$ & 1,601 & 1,601 & 1,601 & 1,601 & 1,601 \\
\hline
\end{tabular}

Source: Families and Employers Survey, 2004-2005 (INED). ${ }^{*} p<0.1 ;{ }^{* *} p<0.05 ;{ }^{* * *} p<0.01$. Other variables (cf. Appendix Table A5). Couple specialization = (woman's time outside employment - man's time outside employment)/couple duration.

\section{Conclusion}

Over the past several decades, we have observed the development of diverse forms of unions in France. Marriage has more and more frequently given way to informal cohabitation or registered partnerships (PACS) while divorce has also become more common, resulting often in new unions that are not necessarily married. Given these evolutions, it is legitimate to ask if the monetary compensation that is awarded when a couple breaks up (spousal alimony) or in the case of a partner's death (survivor's pension) should be reserved exclusively for married couples, as is the case in France to date. Spousal alimony, for instance, is awarded in the event of inequality in the spouses' standards of living. Restricting this right to married unions might be "justified" or "legitimate" if significant differences in wages exist and depend on a couple's status (married, cohabiting) or if inequality between partners is more pronounced within married couples.

We show that, once controlling for selection into marriage (versus cohabitation), marital status does not affect men's hourly wages or women's hourly wages. We do not find evidence of a marriage penalty for women. The marriage premium we observe for men (+ 7\%), without correcting for marriage endogeneity, does not hold once this selection is taken into account. We reach the same conclusion for the difference in wage rates within the couple. When selection is addressed, the larger discrepancies vanish in the intra-couple wage gap within married versus cohabiting couples.

We also highlight that specialization (computed as time spent out of the labor force during the lifetime of a couple) is still a decisive factor for explaining the current gender wage gap, and it is a source of inequality between sexes and between partners within a couple. Regarding women's hourly wages, we show that this specialization has a significant and large impact, and it contributes to explaining their lower hourly wages. 
At this stage, our results show that marital status is of weaker importance relative to the specialization process for explaining the gender wage gap, especially at the moment of divorce. This result is in line with Cohen (2002), who observed that the reduction in the men's marriage wage premium observed over the last 25 years of the $20^{\text {th }}$ century in the United States would be due in part to the increase in the frequency of cohabitation. Because the increase in cohabitation in France has been greater, this could explain the lack of a marriage premium relative to cohabitation. It does not mean, however, that there no longer exists a couple's wage premium, which is still observed in other studies (Meurs et al., 2010); rather, that this premium does not differ for married and cohabiting men. One main reason is that the specialization process, the main driver of this premium, is also observed in unmarried partnerships.

These results tend to confirm the idea that monetary compensation may be eventually extended to unmarried couples if they aim to compensate for losses due to the specialization process. Whereas there could be legal reasons (linked to the marriage contract) for restricting spousal alimony to married partners, there is no economic reason in terms of monetary inequality to reserve this private transfer for married couples. This conclusion is in agreement with certain positions in debates taking place outside of France, such as in Quebec (Comité Consultatif sur le Droit de la Famille, 2015)

The literature so far has been relatively scarce on the comparison between married and unmarried couples, especially with regard to wage premiums and penalties. This article shows that there are no wage differences in France that are linked to being in a married or in an unmarried relationship, but it confirms that being in a co-resident partnership involves couple specialization with adverse effects on gender wage equality. The lack of differences between married and unmarried couples might be country-specific. Indeed, consensual unions have developed in France since the 1970's, and the legal rights associated with the two types of unions tend to be closer, for instance, in terms of parental rights. These findings could have a broader appeal to other studies in various political and cultural contexts.

\section{References}

Aarskaug W.K., Keizer R., Lappegård T. [2012], Relationship Quality in Marital and Cohabiting Unions Across Europe, Journal of Marriage and Family, 74(3), 389-398.

Altonji J.G., Blank R.M. [1999], Race and gender in the labor market, in: Ashenfelter O. and Card D. (eds.), Handbook of Labor Economics, vol. 3., Amsterdam, Elsevier Science, 3143-3259.

Avellar S., Smock P.J. [2005], The economic consequence of the dissolution of cohabitation unions, Journal of Marriage and family, 67(2), 315-327.

Balla N., Bromwich R.J. [2002], Context and Inclusivity in Canada's Evolving Definition of the Family, International Journal of Law, Policy and the Family, 16(2), 145-180.

Bardasi E., Taylor M. [2008], Marriage and Wages: A Test of the Specialization, Economica, 75(299), 569591.

Barg K., Beblo M.S. [2009], Does Marriage pay more than Cohabitation?, Journal of Economic Studies, 36(6), 552-570.

Barg K., Beblo M. [2012], Does "Sorting into Specialization" Explain the Differences in Time Use between Married and Cohabiting Couples? An Empirical Application for Germany, Annals of Economics and Statistics, 105/106, 127-152.

Baxter J. [2005], To marry or not to marry, Journal of Family Issues, 26(3), 300-321. 
Bertrand M., Kamenica E., Pan J. [2015], Gender identity and relative income within households, Quarterly Journal of Economics, 130 (2), 571-614.

Bianchi S., Lesnard L., Nazio T., Raley S. [2014], Gender and time allocation of cohabiting and married women and men in France, Italy, and the United States, Demographic Research, 31(8), 183-216.

Blau F.D. [1998], Trends in the Well-Being of American Women, 1970-1995, Journal of Economic Literature, 36(1), 112-165.

Bloemen H.G., Stancanelli E.G.F. [2014], Market hours, household work, child care, and wage rates of partners: an empirical analysis, Review of Economics of the Household, 12(11), 51-81.

Bloemen H.G., Stancanelli E.G.F. [2015], Toyboys or supergirls? An analysis of partner's employment outcomes when she outearns him, Review of Economics of the Household, 13, 501-530.

Boisson M., Wisnia-Weill V. [2012], Désunion et paternité, Note d'analyse, Centre d'Analyse Stratégique, 294, 1-16.

Bonnet C., Hourriez J.-M. [2012], Gender equality in pensions: what role for rights accrued as a spouse or a parent?, Population, 67(1), 123-146.

Bourreau-Dubois C., Jeandidier B., Sayn I. [2016], Les transferts économiques entre ex-époux à la suite du divorce : logiques alimentaire, compensatoire, indemnitaire ?, Canadian Journal of Law and Society / La Revue Canadienne Droit et Société, 31(2), 135-138.

Brines J., Joyner K. [1999], The Ties That Bind: Principles of Cohesion in Cohabitation and Marriage, American Sociological Review, 64(3), 333-355.

Budig M.J., Lim M. [2016], Cohort Differences and the Mariage Prenium: Emergence of Gender-Neutral Household Specialization Effects, Journal of Marriage and Family, 78(5), 1352-1370.

Cohen P. (2002), Cohabitation and the declining marriage premium for men, Work and Occupations, 29(3), 346-363.

Comité Consultatif sur le Droit de la Famille [2015], Pour un droit de la famille adapté aux nouvelles réalités conjugales et familiales, rapport rédigé sous la présidence d'Alain Roy pour le compte du Ministère de la Justice du Québec.

Conseil d'Orientation des Retraites [2008], Retraites : droits familiaux et droits conjugaux, $6^{\text {ème }}$ rapport, Paris, Ed. La Documentation Française.

Datta Gupta N., Smith N. [2002], Children and Career Interruptions: The Family Gap in Denmark, Economica, 69(276), 609-629.

Datta Gupta N., Smith N., Stratton L.S. [2007], Is marriage poisonous? Are relationships taxing? An analysis of the male marital wage differential in Denmark, Southern Economic Journal, 74(2), 412-433.

Davies R., Pierre G. [2005], The family gap in pay in Europe: A cross-country study, Labour Economics, 12(4), 469-486.

Domínguez-Folgueras M. [2013], Is Cohabitation More Egalitarian? The Division of Household Labor in Five European Countries, Journal of Family Issues, 34(12), 1623-1646.

Dougherty C. [2006], The Marriage Earnings Premium as a Distributed Fixed Effect, Journal of Human Resources, 41(2), 433-43.

El Lahga A., Moreau N. [2007], The effects of marriage on couples' allocation of time between market and non-market hours?, IZA discussion paper (Bonn), 2619, 1-50. 
Frémeaux N. Lefranc A. [2017], Assortative mating and earnings inequality in France, IZA Discussion Paper (Bonn), 11084, 1-47.

Hamplova D., Le Bourdais C. [2009], One Pot or Two Pot Strategies? Income Pooling in Married and Unmarried Households in Comparative Perspective, Journal of Comparative Family Studies, 40(3), 355385.

Hamplová D., Le Bourdais C., Lapierre-Adamcyk É. [2014], Is the Cohabitation-Marriage Gap in Money Pooling Universal?, Journal of Marriage and Family, 76(5), 983-997.

Heimdal K.R., Houseknecht S.K. [2003], Cohabiting and Married Couples' Income Organization: Approaches in Sweden and the United States", Journal of Marriage and Family, 65(3), 525-538.

Heuveline P., Timberlake J.M. [2004], The role of cohabitation in family formation: the United States in comparative perspective, Journal of Marriage and Family, 66(6), 1214-1230.

Hu A., Qian Z. [2015], Educational homogamy and earnings inequality of married couples: Urban China, 1988-2007, Research in Social Stratification and Mobility, 40, 1-15.

Hundley G. [2000], Male/Female Earnings Differences in Self-Employment: The Effects of Marriage, Children, and the Household Division of Labor, Industrial and Labor Relations Review, 54(1), 95-114.

Jacobsen J.P., Rayack W.L. [1996], Do Men Whose Wives Work Really Earn Less?, American Economic Review, 86(2), 268-273.

Kabatek J., van Soest A., Stancanelli E. [2014], Income taxation, labour supply and housework: a discrete choice model for French couples, Labour Economics, 27, 30-43.

Kandil L., Périvier H. [2017], La division sexuée du travail dans les couples selon le statut marital en France : une étude à partir des enquêtes Emploi du temps de 1985-1986, 1998-1999 et 2009-2010, OFCE-Sciences Po Working paper (Paris), 2017-03, 1-40.

Killewald A., Gough M. [2013], Does Specialization Explain Marriage Penalties and Premiums?, American Sociological Review, 78(3), 477-502.

Killewald A. [2013], A Reconsideration of the Fatherhood Premium: Marriage, Coresidence, Biology, and Fathers' Wages, American Sociological Review, 78(1), 96-116.

Light, A. [2004], Gender differences in the marriage and cohabitation income premium, Demography, 41(2), 263-284.

Linde Leonard (de) M., Stanley D. [2015], Married with children: What remains when observable biaises are removed from the reported male marriage wage premium, Labour Economics, 33, 72-80.

Loh E.S. [1996], Productivity Differences and the Marriage Wage Premium for White Males, Journal of Human Resources, 31(3), 566-89.

Mamun A. [2012], Cohabitation Premium in Men's Earnings: Testing the Joint Human Capital Hypothesis, Journal of Family and Economic Issues, 33, 53-68.

Meurs D., Pailhé A., Ponthieux S. [2010], Child related career interruptions and the gender wage gap in France, Annales d'Économie et de Statistiques, 99/100, 15-46.

Morin T. [2014], Ecarts de revenus au sein des couples, INSEE Première, 1492, 1-4.

Osborne C., Manning W.D., Smock P.J. [2007], Married and Cohabiting Parents' Relationship Stability: A Focus on Race and Ethnicity, Journal of Marriage and Family, 69(5), 1345-1366. 
Perelli-Harris B., Kreyenfeld M., Sigle-Rushton W., Keizer R., Lappegard T., Jasilioniene A., Berghammer C., Di Giulio P. [2012], Changes in union status during the transition to parenthood in eleven European countries, 1970s to early 2000s, Population Studies, 66(2), 167-182.

Perelli-Harris B., Gassen, N.S. [2012], How Similar Are Cohabitation and Marriage? Legal Approaches to Cohabitation across Western Europe, Population and Development Review, 38(3), 435-467.

Perelli-Harris B. [2014], How Similar are Cohabiting and Married Parents? Second Conception Risks by Union Type in the United States and Across Europe, European Journal of Population, 30(4), 437-464.

Petersen T., Penner A.M., Hogsnes G. [2011], The Male Marital Wage Premium: Sorting vs. Differential Pay, Industrial and Labor Relations Review, 64(2), 283-304.

Pollmann-Schult M. [2011], Marriage and Earnings: Why Do Married Men Earn More than Single Men?, European Sociological Review, 27(2), 147-163.

Ponthieux S., Schreiber A. [2006], Dans les couples de salariés, la répartition du travail domestique reste inégale, in: INSEE (eds.), Données sociales, la société française, Paris, Insee, 43-51.

Ponthieux S. [2012], La mise en commun des revenus dans les couples, INSEE Première, 1409, 1-4.

Ponthieux S., Meurs D. [2015], Gender inequality, in: Atkinson A. and Bourguignon F. (eds.), Handbook of Income Distribution, Vol. 2 A., 881-1146.

Poortman A.-R., Mills M. [2012], Investments in Marriage and Cohabitation: The Role of Legal and Interpersonal Commitment, Journal of Marriage and Family, 74(2), 357-376.

Prioux F. [2009], Les couples non mariés en 2005: quelles différences avec les couples mariés?, Politiques sociales et familiales, 96, 87-95.

Ravazzini L., Kuhn U., Suter, C. [2017], Do Opposites Attract? Educational Assortative Mating and Dynamics of Wage Homogamy in Switzerland, 1992-2014, Swiss Journal of Sociology, 43(3), 567-586.

Schoeni R.F. [1995], Marital Status and Earnings in Developed Countries, Journal of Population Economics, 8(4), 351-59.

Schwartz C.R. [2010], Pathways to educational homogamy in marital and cohabiting unions, Demography, 47(3), 735-753.

Sobotka T., Toulemon, L. [2008], Overview Chapter 4, Changing family and partnership behavior: common trends and persistent diversity across Europe, Demographic Research, 19(6), 85-138.

Sofer C., Thibout C. [2015], La division du travail selon le genre est-elle efficiente ? Une analyse à partir de deux enquêtes Emploi du temps, Economie et Statistiques, 478/479/480, 273-304.

Soons, J. P. M., Kalmijn M. [2009], Is Marriage More Than Cohabitation? Well-Being Differences in 30 European Countries, Journal of Marriage and Family, 71(5), 1141-1157.

South S.J., Spitze G. [1994], Housework in marital and non-marital households, American Sociological Review, 59(3), 327-347.

Stratton L. [2002], Examining the Wage Differential for Married and Cohabitating Men, Economic Inquiry, 40(2), 199-212.

Vanderschelden M. [2006], Les ruptures d'unions: plus fréquentes, mais pas plus précoces, Insee Première, 1107, 1-4. 
Volker L., Brüderl J. [2018], Is There a Male Marital Wage Premium? New Evidence from the United States, American Sociological Review, 83(4), 744-770.

Winkler A. [1997], Economic decision-making by cohabitors: findings regarding income pooling, Applied Economics, 29, 1079-1090. 
Appendix

Table A1. Estimation of women's hourly wage rate (Log)

\begin{tabular}{|c|c|c|c|c|}
\hline & $\begin{array}{l}\text { OLS } \\
\text { (1) }\end{array}$ & $\begin{array}{l}\text { OLS } \\
(2)\end{array}$ & $\begin{array}{l}\text { OLS } \\
\text { (3) }\end{array}$ & $\begin{array}{l}\text { IV } \\
\text { (4) }\end{array}$ \\
\hline Married & $\begin{array}{c}-0.001 \\
(0.020)\end{array}$ & $\begin{array}{l}-0.024 \\
(0.017)\end{array}$ & $\begin{array}{l}-0.029 * \\
(0.017)\end{array}$ & $\begin{array}{l}-0.071 \\
(0.111)\end{array}$ \\
\hline Age & $\begin{array}{l}0.009 * * * \\
(0.001)\end{array}$ & $\begin{array}{l}-0.007^{*} \\
(0.004)\end{array}$ & $\begin{array}{l}-0.004 \\
(0.003)\end{array}$ & $\begin{array}{l}-0.003 \\
(0.004)\end{array}$ \\
\hline 1 child & $\begin{array}{l}-0.044 \\
(0.034)\end{array}$ & $\begin{array}{l}-0.010 \\
(0.026)\end{array}$ & $\begin{array}{l}-0.016 \\
(0.025)\end{array}$ & $\begin{array}{l}-0.007 \\
(0.032)\end{array}$ \\
\hline 2 children & $\begin{array}{l}-0.066 \\
(0.044)\end{array}$ & $\begin{array}{l}-0.020 \\
(0.028)\end{array}$ & $\begin{array}{l}-0.026 \\
(0.027)\end{array}$ & $\begin{array}{l}-0.012 \\
(0.046)\end{array}$ \\
\hline 3 or more & $\begin{array}{c}-0.159 * \\
(0.085)\end{array}$ & $\begin{array}{l}-0.011 \\
(0.034)\end{array}$ & $\begin{array}{l}-0.028 \\
(0.033)\end{array}$ & $\begin{array}{l}-0.013 \\
(0.050)\end{array}$ \\
\hline Second union & $\begin{array}{c}0.041^{*} \\
(0.025)\end{array}$ & $\begin{array}{c}0.039 * \\
(0.021)\end{array}$ & $\begin{array}{l}0.045^{* *} \\
(0.020)\end{array}$ & $\begin{array}{c}0.033 \\
(0.037)\end{array}$ \\
\hline Non-native & $\begin{array}{l}-0.115 \\
(0.083)\end{array}$ & $\begin{array}{c}0.065 \\
(0.046)\end{array}$ & $\begin{array}{l}0.094 * * \\
(0.044)\end{array}$ & $\begin{array}{l}0.100 * * \\
(0.047)\end{array}$ \\
\hline Paris and suburbs & $\begin{array}{l}0.199 * * * \\
(0.027)\end{array}$ & $\begin{array}{l}0.085^{* * *} \\
(0.022)\end{array}$ & $\begin{array}{l}0.079 * * * \\
(0.021)\end{array}$ & $\begin{array}{l}0.077^{* * *} \\
(0.022)\end{array}$ \\
\hline University 3rd cycle & & $\begin{array}{l}0.788 * * * \\
(0.045)\end{array}$ & $\begin{array}{l}0.629 * * * \\
(0.045)\end{array}$ & $\begin{array}{l}0.632 * * * \\
(0.046)\end{array}$ \\
\hline University 2nd cycle & & $\begin{array}{l}0.620 * * * \\
(0.040)\end{array}$ & $\begin{array}{l}0.467 * * * \\
(0.039)\end{array}$ & $\begin{array}{l}0.468 * * * \\
(0.039)\end{array}$ \\
\hline University 1st cycle & & $\begin{array}{l}0.446 * * * \\
(0.034)\end{array}$ & $\begin{array}{l}0.345^{* * *} \\
(0.034)\end{array}$ & $\begin{array}{l}0.347^{* * *} \\
(0.035)\end{array}$ \\
\hline Baccalauréat & & $\begin{array}{l}0.280 * * * \\
(0.032)\end{array}$ & $\begin{array}{l}0.217^{* * *} \\
(0.031)\end{array}$ & $\begin{array}{l}0.217^{* * *} \\
(0.031)\end{array}$ \\
\hline CAP diploma & & $\begin{array}{l}0.129 * * * \\
(0.028)\end{array}$ & $\begin{array}{l}0.101 * * * \\
(0.028)\end{array}$ & $\begin{array}{l}0.100 * * * \\
(0.028)\end{array}$ \\
\hline Brevet diploma & & $\begin{array}{c}0.059 * \\
(0.034)\end{array}$ & $\begin{array}{c}0.055^{*} \\
(0.032)\end{array}$ & $\begin{array}{c}0.056^{*} \\
(0.033)\end{array}$ \\
\hline Real experience & & $\begin{array}{l}0.038^{* * *} \\
(0.007)\end{array}$ & $\begin{array}{l}0.028 * * * \\
(0.007)\end{array}$ & $\begin{array}{l}0.028 * * * \\
(0.007)\end{array}$ \\
\hline Square of real experience & & $\begin{array}{l}-0.000 * * * \\
(0.000)\end{array}$ & $\begin{array}{l}-0.000 * * * \\
(0.000)\end{array}$ & $\begin{array}{l}-0.000 * * * \\
(0.000)\end{array}$ \\
\hline Health problems during lifetime & & $\begin{array}{l}-0.054^{* *} \\
(0.023)\end{array}$ & $\begin{array}{l}-0.057^{* *} \\
(0.023)\end{array}$ & $\begin{array}{l}-0.055^{* *} \\
(0.024)\end{array}$ \\
\hline Tenure & & & $\begin{array}{l}0.006 * * * \\
(0.001)\end{array}$ & $\begin{array}{l}0.006 * * * \\
(0.001)\end{array}$ \\
\hline Position with responsibilities & & & $\begin{array}{l}0.136^{* * *} \\
(0.019)\end{array}$ & $\begin{array}{l}0.135^{* * *} \\
(0.019)\end{array}$ \\
\hline Public sector & & & $\begin{array}{l}0.092 * * * \\
(0.024)\end{array}$ & $\begin{array}{l}0.092 * * * \\
(0.024)\end{array}$ \\
\hline Industrial \& construction & & & $\begin{array}{c}0.043 \\
(0.033)\end{array}$ & $\begin{array}{c}0.043 \\
(0.033)\end{array}$ \\
\hline Finance, services for companies & & & $\begin{array}{l}0.109 * * * \\
(0.033)\end{array}$ & $\begin{array}{l}0.110 * * * \\
(0.033)\end{array}$ \\
\hline Real estate, trade, services for household & & & $\begin{array}{l}-0.037 \\
(0.032)\end{array}$ & $\begin{array}{l}-0.037 \\
(0.032)\end{array}$ \\
\hline Education \& health sector & & & $\begin{array}{l}0.059 * * * \\
(0.023)\end{array}$ & $\begin{array}{l}0.060 * * * \\
(0.023)\end{array}$ \\
\hline$<20$ employees & & & $\begin{array}{l}-0.118^{* * *} \\
(0.028)\end{array}$ & $\begin{array}{l}-0.119 * * * \\
(0.028)\end{array}$ \\
\hline
\end{tabular}


20-49 employees

50-50 employees

200-499 employees

500-999 employees

Inverse Mill's ratio

Constant

$R^{2}$

$N$

\begin{tabular}{cccc} 
& & -0.050 & $-0.054^{*}$ \\
& & $(0.031)$ & $(0.033)$ \\
& & -0.033 & -0.035 \\
& & $(0.029)$ & $(0.029)$ \\
& & $-0.078^{* * *}$ & $-0.080^{* * *}$ \\
& & $(0.030)$ & $(0.031)$ \\
0.144 & & -0.034 & -0.034 \\
$(0.175)$ & $0.160^{* *}$ & $(0.035)$ & $(0.036)$ \\
$1.800^{* * *}$ & $(0.080)$ & 0.108 & 0.109 \\
$(0.048)$ & $1.645^{* * *}$ & $(0.078)$ & $(0.078)$ \\
0.05 & $(0.069)$ & $(0.080)$ & $1.685^{* * *}$ \\
2,275 & 0.32 & 0.39 & $(0.080)$ \\
& 2,275 & 2,275 & 0.39 \\
& & 2,275 \\
\hline
\end{tabular}
significant at 1\% level. Reference group: no diploma, no children, public sector, 100 to 199 employees. 
Table A2. Estimation of men's hourly wage rate (Log)

\begin{tabular}{|c|c|c|c|c|}
\hline & $\begin{array}{l}\text { OLS } \\
(1)\end{array}$ & $\begin{array}{l}\text { OLS } \\
(2)\end{array}$ & $\begin{array}{l}\text { OLS } \\
(3)\end{array}$ & $\begin{array}{l}\text { IV } \\
(4)\end{array}$ \\
\hline Married & $\begin{array}{l}0.113^{* * * *} \\
(0.018)\end{array}$ & $\begin{array}{l}0.075^{* * * *} \\
(0.016)\end{array}$ & $\begin{array}{l}0.071 * * * \\
(0.015)\end{array}$ & $\begin{array}{l}-0.131 \\
(0.121)\end{array}$ \\
\hline Age & $\begin{array}{l}0.010^{* * * *} \\
(0.001)\end{array}$ & $\begin{array}{c}0.006 \\
(0.005)\end{array}$ & $\begin{array}{c}0.006 \\
(0.005)\end{array}$ & $\begin{array}{l}0.006 \\
(0.005)\end{array}$ \\
\hline 1 child & $\begin{array}{c}0.004 \\
(0.023)\end{array}$ & $\begin{array}{c}0.032 \\
(0.021)\end{array}$ & $\begin{array}{c}0.034^{*} \\
(0.020)\end{array}$ & $\begin{array}{l}0.082^{* *} \\
(0.036)\end{array}$ \\
\hline 2 children & $\begin{array}{c}0.029 \\
(0.023)\end{array}$ & $\begin{array}{l}0.070 * * * \\
(0.021)\end{array}$ & $\begin{array}{l}0.065^{* * * *} \\
(0.020)\end{array}$ & $\begin{array}{l}0.133^{* * *} \\
(0.047)\end{array}$ \\
\hline 3 or more & $\begin{array}{l}-0.001 \\
(0.028)\end{array}$ & $\begin{array}{l}0.050 * * \\
(0.024)\end{array}$ & $\begin{array}{l}0.045^{* *} \\
(0.023)\end{array}$ & $\begin{array}{l}0.121^{* *} \\
(0.051)\end{array}$ \\
\hline Second union & $\begin{array}{c}0.002 \\
(0.021)\end{array}$ & $\begin{array}{c}0.012 \\
(0.019)\end{array}$ & $\begin{array}{c}0.019 \\
(0.018)\end{array}$ & $\begin{array}{l}-0.033 \\
(0.035)\end{array}$ \\
\hline Non native & $\begin{array}{l}-0.196 * * * \\
(0.037)\end{array}$ & $\begin{array}{l}-0.104^{* * *} \\
(0.032)\end{array}$ & $\begin{array}{l}-0.074^{* *} \\
(0.030)\end{array}$ & $\begin{array}{l}-0.043 \\
(0.036)\end{array}$ \\
\hline Paris and suburbs & $\begin{array}{l}0.279 * * * \\
(0.025)\end{array}$ & $\begin{array}{l}0.135^{* * *} \\
(0.020)\end{array}$ & $\begin{array}{l}0.126^{* * *} \\
(0.020)\end{array}$ & $\begin{array}{l}0.112^{* * *} \\
(0.022)\end{array}$ \\
\hline University 3rd cycle & & $\begin{array}{l}0.794^{* * * *} \\
(0.039)\end{array}$ & $\begin{array}{l}0.689 * * * \\
(0.040)\end{array}$ & $\begin{array}{l}0.721 * * * \\
(0.045)\end{array}$ \\
\hline University 2nd cycle & & $\begin{array}{l}0.487 * * * \\
(0.041)\end{array}$ & $\begin{array}{l}0.413^{* * *} \\
(0.041)\end{array}$ & $\begin{array}{l}0.445^{* * *} \\
(0.046)\end{array}$ \\
\hline University 1st cycle & & $\begin{array}{l}0.388^{* * * *} \\
(0.029)\end{array}$ & $\begin{array}{l}0.328 * * * \\
(0.029)\end{array}$ & $\begin{array}{l}0.346^{* * *} \\
(0.031)\end{array}$ \\
\hline Baccalauréat & & $\begin{array}{l}0.283^{* * *} \\
(0.025)\end{array}$ & $\begin{array}{l}0.236^{* * * *} \\
(0.025)\end{array}$ & $\begin{array}{l}0.249 * * * \\
(0.027)\end{array}$ \\
\hline CAP diploma & & $\begin{array}{l}0.101^{* * *} \\
(0.019)\end{array}$ & $\begin{array}{l}0.082 * * * \\
(0.018)\end{array}$ & $\begin{array}{l}0.093^{* * *} \\
(0.021)\end{array}$ \\
\hline Brevet diploma & & $\begin{array}{l}0.170 * * * \\
(0.028)\end{array}$ & $\begin{array}{l}0.139 * * * \\
(0.027)\end{array}$ & $\begin{array}{l}0.136 * * * \\
(0.029)\end{array}$ \\
\hline Real experience & & $\begin{array}{l}0.023^{* * *} \\
(0.006)\end{array}$ & $\begin{array}{l}0.019 * * * \\
(0.006)\end{array}$ & $\begin{array}{l}0.023^{* * *} \\
(0.006)\end{array}$ \\
\hline Square of real experience & & $\begin{array}{l}-0.000 * * * \\
(0.000)\end{array}$ & $\begin{array}{l}-0.000 * * * \\
(0.000)\end{array}$ & $\begin{array}{l}-0.000 * * * \\
(0.000)\end{array}$ \\
\hline Health problems during lifetime & & $\begin{array}{l}-0.035^{*} \\
(0.019)\end{array}$ & $\begin{array}{l}-0.044^{* *} \\
(0.018)\end{array}$ & $\begin{array}{l}-0.039 * * \\
(0.020)\end{array}$ \\
\hline Tenure & & & $\begin{array}{l}0.002^{* *} \\
(0.001)\end{array}$ & $\begin{array}{l}0.003^{* *} \\
(0.001)\end{array}$ \\
\hline Position with responsibilities & & & $\begin{array}{l}0.131^{* * *} \\
(0.014)\end{array}$ & $\begin{array}{l}0.136^{* * *} \\
(0.015)\end{array}$ \\
\hline Public sector & & & $\begin{array}{r}0.060 \\
(0.037)\end{array}$ & $\begin{array}{c}0.055 \\
(0.037)\end{array}$ \\
\hline Industrial \& construction & & & $\begin{array}{c}0.070^{*} \\
(0.041)\end{array}$ & $\begin{array}{c}0.058 \\
(0.041)\end{array}$ \\
\hline Finance, services for companies & & & $\begin{array}{l}0.112^{* * *} \\
(0.040)\end{array}$ & $\begin{array}{l}0.108^{* * *} \\
(0.040)\end{array}$ \\
\hline Real estate, trade, services for household & & & $\begin{array}{c}0.013 \\
(0.045)\end{array}$ & $\begin{array}{c}0.003 \\
(0.045)\end{array}$ \\
\hline Education \& health sector & & & $\begin{array}{c}0.052 \\
(0.036)\end{array}$ & $\begin{array}{c}0.047 \\
(0.036)\end{array}$ \\
\hline$<20$ employees & & & $\begin{array}{l}-0.143^{* * *} \\
(0.024)\end{array}$ & $\begin{array}{l}-0.137^{* * *} \\
(0.025)\end{array}$ \\
\hline 20-49 employees & & & $\begin{array}{l}-0.078^{* * *} \\
(0.026)\end{array}$ & $\begin{array}{l}-0.077^{* * *} \\
(0.027)\end{array}$ \\
\hline
\end{tabular}


50-50 employees

200-499 employees

500-999 employees

Constant

$R^{2}$

$N$

$1.822 * * *$

(0.043)

0.13

2,375

\begin{tabular}{ll}
$-0.051^{* *}$ & $-0.056^{* *}$ \\
$(0.022)$ & $(0.023)$ \\
-0.025 & -0.022 \\
$(0.027)$ & $(0.028)$ \\
-0.037 & -0.032 \\
$(0.027)$ & $(0.028)$ \\
$1.559 * * *$ & $1.576^{* * *}$ \\
$(0.117)$ & $(0.115)$ \\
0.42 & 0.38 \\
2,375 & 2,375 \\
\hline
\end{tabular}

significant at 1\% level. Reference group: no diploma, no children, public sector, 100 to 199 employees. 
Table A3. Estimation of men's and women's hourly wage rates (log), specialization indicators

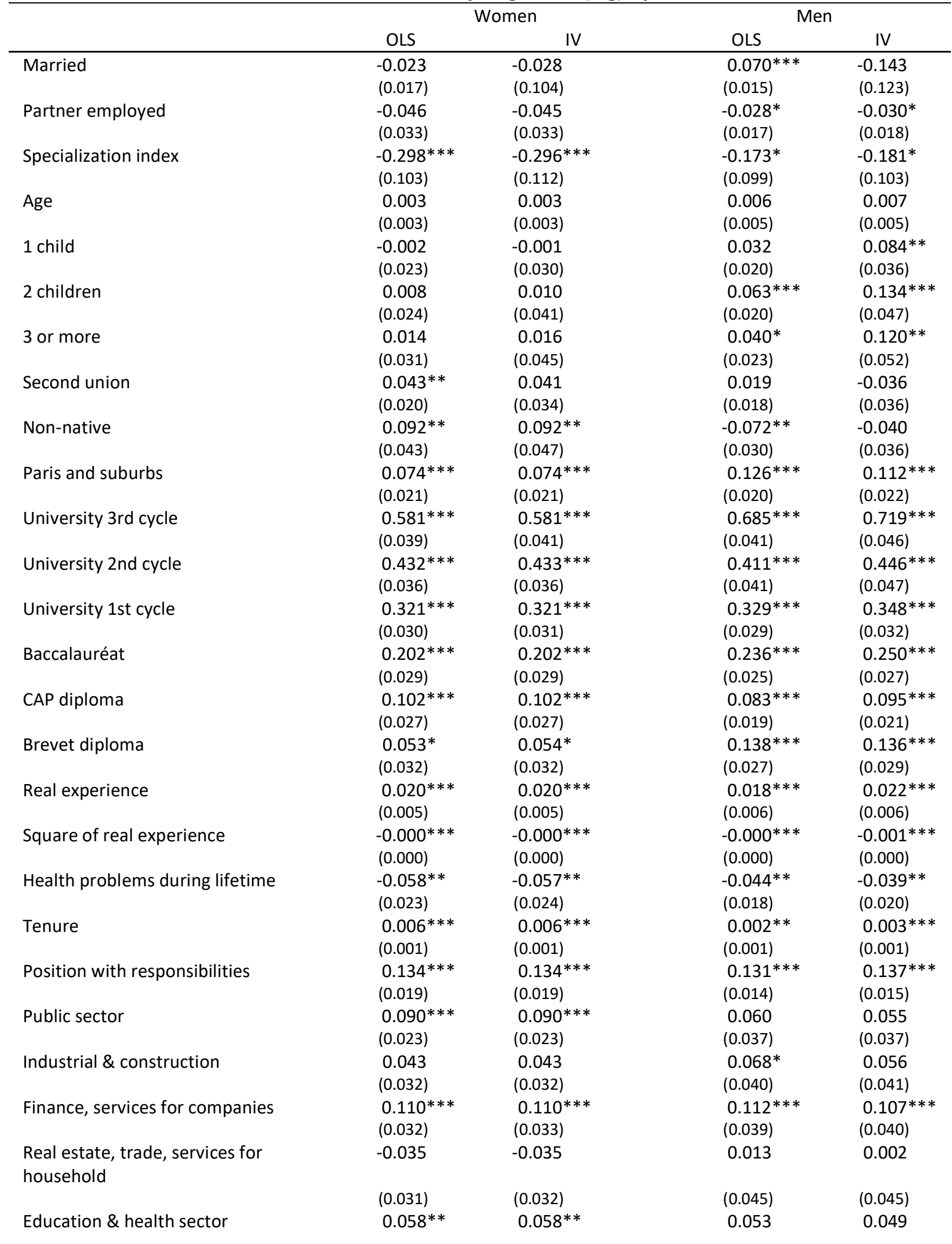




\begin{tabular}{|c|c|c|c|c|}
\hline & $(0.023)$ & $(0.023)$ & $(0.036)$ & $(0.036)$ \\
\hline \multirow[t]{2}{*}{$<20$ employees } & $-0.118^{* * *}$ & $-0.118^{* * *}$ & $-0.145^{* * *}$ & $-0.138 * * *$ \\
\hline & $(0.028)$ & $(0.028)$ & $(0.024)$ & $(0.025)$ \\
\hline \multirow[t]{2}{*}{ 20-49 employees } & -0.048 & -0.049 & $-0.078 * * *$ & $-0.077 * * *$ \\
\hline & $(0.031)$ & $(0.032)$ & $(0.026)$ & $(0.027)$ \\
\hline \multirow[t]{2}{*}{ 50-50 employees } & -0.031 & -0.031 & $-0.052 * *$ & $-0.057 * *$ \\
\hline & $(0.029)$ & $(0.029)$ & $(0.022)$ & $(0.023)$ \\
\hline \multirow[t]{2}{*}{ 200-499 employees } & $-0.076 * *$ & $-0.076 * *$ & -0.024 & -0.021 \\
\hline & $(0.030)$ & $(0.031)$ & $(0.026)$ & $(0.028)$ \\
\hline \multirow[t]{2}{*}{ 500-999 employees } & -0.029 & -0.029 & -0.039 & -0.033 \\
\hline & $(0.035)$ & $(0.035)$ & $(0.027)$ & $(0.028)$ \\
\hline \multirow[t]{2}{*}{ Inverse Mill's ratio } & $0.141^{*}$ & $0.140 *$ & & \\
\hline & $(0.084)$ & $(0.085)$ & & \\
\hline \multirow[t]{2}{*}{ Constant } & $1.624^{* * *}$ & $1.625^{* * *}$ & $1.570 * * *$ & $1.589 * * *$ \\
\hline & $(0.086)$ & $(0.086)$ & $(0.118)$ & $(0.116)$ \\
\hline$R^{2}$ & 0.39 & 0.39 & 0.42 & 0.38 \\
\hline$N$ & 2,275 & 2,275 & 2,375 & 2,375 \\
\hline
\end{tabular}

Source: Families and Employers Survey, $2004-2005$ (INED). ${ }^{*} p<0.1 ;{ }^{* *} p<0.05 ;{ }^{* * *} p<0.01$. Reference group: no diploma, no children, public sector, 100 to 199 employees. 
Table A4. First stage equations

\begin{tabular}{|c|c|c|c|c|}
\hline IV model from & $\begin{array}{l}\text { Women } \\
\text { Table } 4\end{array}$ & Table 6 & $\begin{array}{c}\text { Men } \\
\text { Table } 5\end{array}$ & Table 6 \\
\hline Religion important & $\begin{array}{l}0.483^{* * *} \\
(0.081)\end{array}$ & $\begin{array}{l}0.487^{* * *} \\
(0.082)\end{array}$ & $\begin{array}{l}0.525^{* * *} \\
(0.092)\end{array}$ & $\begin{array}{l}0.524^{* * *} \\
(0.092)\end{array}$ \\
\hline Partner employed & & $\begin{array}{c}0.216^{*} \\
(0.130)\end{array}$ & & $\begin{array}{l}-0.028 \\
(0.074)\end{array}$ \\
\hline Specialization index & & $\begin{array}{l}1.276 * * * \\
(0.495)\end{array}$ & & $\begin{array}{l}-0.267 \\
(0.496)\end{array}$ \\
\hline Age & $\begin{array}{l}0.047^{* * *} \\
(0.015)\end{array}$ & $\begin{array}{l}0.034^{* * *} \\
(0.012)\end{array}$ & $\begin{array}{c}0.003 \\
(0.013)\end{array}$ & $\begin{array}{c}0.004 \\
(0.014)\end{array}$ \\
\hline 1 child & $\begin{array}{l}0.543^{* * *} \\
(0.106)\end{array}$ & $\begin{array}{l}0.542^{* * *} \\
(0.097)\end{array}$ & $\begin{array}{l}0.664^{* * *} \\
(0.091)\end{array}$ & $\begin{array}{l}0.663^{* * *} \\
(0.091)\end{array}$ \\
\hline 2 children & $\begin{array}{l}1.004^{* * *} \\
(0.114)\end{array}$ & $\begin{array}{l}0.915^{* * *} \\
(0.104)\end{array}$ & $\begin{array}{l}0.975^{* * *} \\
(0.092)\end{array}$ & $\begin{array}{l}0.973^{* * *} \\
(0.093)\end{array}$ \\
\hline 3 or more & $\begin{array}{l}1.120 * * * \\
(0.146)\end{array}$ & $\begin{array}{l}0.997 * * * \\
(0.136)\end{array}$ & $\begin{array}{l}1.154 * * * \\
(0.114)\end{array}$ & $\begin{array}{l}1.151^{* * *} \\
(0.116)\end{array}$ \\
\hline Second union & $\begin{array}{l}-0.929 * * * \\
(0.080)\end{array}$ & $\begin{array}{l}-0.907^{* * *} \\
(0.080)\end{array}$ & $\begin{array}{l}-0.810^{* * *} \\
(0.074)\end{array}$ & $\begin{array}{l}-0.811 * * * \\
(0.074)\end{array}$ \\
\hline Non-native & $\begin{array}{l}0.375^{* *} \\
(0.156)\end{array}$ & $\begin{array}{l}0.408^{* * *} \\
(0.157)\end{array}$ & $\begin{array}{l}0.474^{* * *} \\
(0.141)\end{array}$ & $\begin{array}{l}0.479 * * * \\
(0.141)\end{array}$ \\
\hline Paris and sub. & $\begin{array}{l}-0.187^{* *} \\
(0.087)\end{array}$ & $\begin{array}{c}-0.164^{*} \\
(0.088)\end{array}$ & $\begin{array}{l}-0.294^{* * *} \\
(0.085)\end{array}$ & $\begin{array}{l}-0.294 * * * \\
(0.085)\end{array}$ \\
\hline University 3rd cycle & $\begin{array}{c}0.323^{*} \\
(0.185)\end{array}$ & $\begin{array}{l}0.399 * * \\
(0.165)\end{array}$ & $\begin{array}{l}0.628 * * * \\
(0.159)\end{array}$ & $\begin{array}{l}0.620 * * * \\
(0.160)\end{array}$ \\
\hline University 2 nd cycle & $\begin{array}{c}0.118 \\
(0.155)\end{array}$ & $\begin{array}{c}0.187 \\
(0.145)\end{array}$ & $\begin{array}{l}0.650 * * * \\
(0.159)\end{array}$ & $\begin{array}{l}0.646 * * * \\
(0.160)\end{array}$ \\
\hline University 1st cycle & $\begin{array}{c}0.251^{*} \\
(0.146)\end{array}$ & $\begin{array}{l}0.286^{* *} \\
(0.138)\end{array}$ & $\begin{array}{l}0.406 * * * \\
(0.138)\end{array}$ & $\begin{array}{l}0.405^{* * *} \\
(0.139)\end{array}$ \\
\hline Baccalauréat & $\begin{array}{c}0.097 \\
(0.129)\end{array}$ & $\begin{array}{c}0.123 \\
(0.127)\end{array}$ & $\begin{array}{l}0.308^{* *} \\
(0.123)\end{array}$ & $\begin{array}{l}0.308^{* *} \\
(0.123)\end{array}$ \\
\hline CAP diploma & $\begin{array}{r}0.000 \\
(0.119)\end{array}$ & $\begin{array}{l}-0.023 \\
(0.119)\end{array}$ & $\begin{array}{l}0.248^{* *} \\
(0.101)\end{array}$ & $\begin{array}{l}0.248^{* *} \\
(0.101)\end{array}$ \\
\hline Brevet diploma & $\begin{array}{c}0.138 \\
(0.166)\end{array}$ & $\begin{array}{c}0.151 \\
(0.168)\end{array}$ & $\begin{array}{c}0.014 \\
(0.142)\end{array}$ & $\begin{array}{c}0.012 \\
(0.142)\end{array}$ \\
\hline Real experience & $\begin{array}{l}-0.008 \\
(0.031)\end{array}$ & $\begin{array}{l}-0.003 \\
(0.022)\end{array}$ & $\begin{array}{l}0.068 * * * \\
(0.021)\end{array}$ & $\begin{array}{l}0.067 * * * \\
(0.021)\end{array}$ \\
\hline Square of real experience & $\begin{array}{r}0.000 \\
(0.001)\end{array}$ & $\begin{array}{c}0.000 \\
(0.001)\end{array}$ & $\begin{array}{l}-0.001 * \\
(0.001)\end{array}$ & $\begin{array}{l}-0.001 * \\
(0.001)\end{array}$ \\
\hline Health problems during lifetime & $\begin{array}{l}0.212^{* *} \\
(0.102)\end{array}$ & $\begin{array}{l}0.204^{* *} \\
(0.102)\end{array}$ & $\begin{array}{r}0.081 \\
(0.094)\end{array}$ & $\begin{array}{c}0.083 \\
(0.094)\end{array}$ \\
\hline Tenure & $\begin{array}{c}0.008 \\
(0.006)\end{array}$ & $\begin{array}{c}0.009 \\
(0.006)\end{array}$ & $\begin{array}{r}0.006 \\
(0.005)\end{array}$ & $\begin{array}{r}0.006 \\
(0.005)\end{array}$ \\
\hline Position with responsibilities & $\begin{array}{l}-0.039 \\
(0.087)\end{array}$ & $\begin{array}{l}-0.025 \\
(0.087)\end{array}$ & $\begin{array}{r}0.104 \\
(0.066)\end{array}$ & $\begin{array}{c}0.104 \\
(0.066)\end{array}$ \\
\hline Public sector & $\begin{array}{l}-0.030 \\
(0.103)\end{array}$ & $\begin{array}{l}-0.018 \\
(0.104)\end{array}$ & $\begin{array}{l}-0.079 \\
(0.135)\end{array}$ & $\begin{array}{l}-0.078 \\
(0.135)\end{array}$ \\
\hline Industrial \& construction & $\begin{array}{c}0.018 \\
(0.142)\end{array}$ & $\begin{array}{c}0.012 \\
(0.142)\end{array}$ & $\begin{array}{l}-0.184 \\
(0.156)\end{array}$ & $\begin{array}{l}-0.185 \\
(0.157)\end{array}$ \\
\hline Finance, services for companies & $\begin{array}{c}0.136 \\
(0.144)\end{array}$ & $\begin{array}{c}0.121 \\
(0.145)\end{array}$ & $\begin{array}{l}-0.037 \\
(0.156)\end{array}$ & $\begin{array}{l}-0.037 \\
(0.156)\end{array}$ \\
\hline Real estate, trade, services for household & -0.006 & -0.020 & -0.141 & -0.141 \\
\hline
\end{tabular}




\begin{tabular}{|c|c|c|c|c|}
\hline & $(0.131)$ & $(0.131)$ & $(0.164)$ & $(0.164)$ \\
\hline Education \& health sector & $\begin{array}{c}0.035 \\
(0.105)\end{array}$ & $\begin{array}{r}0.030 \\
(0.106)\end{array}$ & $\begin{array}{l}-0.028 \\
(0.146)\end{array}$ & $\begin{array}{l}-0.027 \\
(0.146)\end{array}$ \\
\hline$<20$ employees & $\begin{array}{l}-0.079 \\
(0.121)\end{array}$ & $\begin{array}{l}-0.085 \\
(0.122)\end{array}$ & $\begin{array}{c}0.082 \\
(0.111)\end{array}$ & $\begin{array}{c}0.079 \\
(0.111)\end{array}$ \\
\hline 20-49 employees & $\begin{array}{l}-0.266^{* *} \\
(0.135)\end{array}$ & $\begin{array}{l}-0.282^{* *} \\
(0.135)\end{array}$ & $\begin{array}{r}0.020 \\
(0.125)\end{array}$ & $\begin{array}{r}0.020 \\
(0.125)\end{array}$ \\
\hline 50-50 employees & $\begin{array}{l}-0.160 \\
(0.125)\end{array}$ & $\begin{array}{l}-0.168 \\
(0.126)\end{array}$ & $\begin{array}{l}-0.084 \\
(0.108)\end{array}$ & $\begin{array}{l}-0.085 \\
(0.108)\end{array}$ \\
\hline 200-499 employees & $\begin{array}{l}-0.121 \\
(0.135)\end{array}$ & $\begin{array}{l}-0.128 \\
(0.136)\end{array}$ & $\begin{array}{c}0.067 \\
(0.121)\end{array}$ & $\begin{array}{c}0.068 \\
(0.122)\end{array}$ \\
\hline 500-999 employees & $\begin{array}{l}-0.032 \\
(0.165)\end{array}$ & $\begin{array}{l}-0.064 \\
(0.166)\end{array}$ & $\begin{array}{c}0.110 \\
(0.140)\end{array}$ & $\begin{array}{c}0.108 \\
(0.140)\end{array}$ \\
\hline Inverse Mill's ratio & $\begin{array}{c}0.253 \\
(0.367)\end{array}$ & $\begin{array}{l}-0.169 \\
(0.437)\end{array}$ & & \\
\hline Constant & $\begin{array}{l}-1.820 * * * \\
(0.344)\end{array}$ & $\begin{array}{l}-1.744^{* * *} \\
(0.361)\end{array}$ & $\begin{array}{l}-1.327^{* * *} \\
(0.371)\end{array}$ & $\begin{array}{l}-1.322^{* * *} \\
(0.373)\end{array}$ \\
\hline F-stat & 32.03 & 32.94 & 31.75 & 31.53 \\
\hline$N$ & 2,275 & 2,275 & 2,375 & 2,375 \\
\hline
\end{tabular}

Source: Families and Employers Survey, 2004-2005 (INED). ${ }^{*} p<0.1 ;^{* *} p<0.05 ;{ }^{* * *} p<0.01$. 
Table A5. Estimation of the difference between men's and women's hourly wage rates (log) within couples

\begin{tabular}{|c|c|c|c|c|c|}
\hline & $\begin{array}{l}\text { OLS } \\
\text { (1) }\end{array}$ & $\begin{array}{l}\text { OLS } \\
(2)\end{array}$ & $\begin{array}{l}\text { OLS } \\
\text { (3) }\end{array}$ & $\begin{array}{l}\text { OLS } \\
\text { (4) }\end{array}$ & $\begin{array}{l}\text { IV } \\
\text { (5) }\end{array}$ \\
\hline Married & $\begin{array}{l}0.071^{* *} \\
(0.028)\end{array}$ & $\begin{array}{l}0.071 * * \\
(0.028)\end{array}$ & $\begin{array}{l}0.072^{* * *} \\
(0.027)\end{array}$ & $\begin{array}{l}0.061 * * \\
(0.027)\end{array}$ & $\begin{array}{c}0.042 \\
(0.133)\end{array}$ \\
\hline Couple specialization & & & & $\begin{array}{l}0.458^{* * * *} \\
(0.126)\end{array}$ & $\begin{array}{l}0.478 * * * \\
(0.142)\end{array}$ \\
\hline M Age & $\begin{array}{l}0.014^{* * *} \\
(0.004)\end{array}$ & $\begin{array}{l}0.019 * * * \\
(0.006)\end{array}$ & $\begin{array}{l}0.018^{* * *} \\
(0.006)\end{array}$ & $\begin{array}{l}0.020 * * * \\
(0.006)\end{array}$ & $\begin{array}{l}0.020 * * * \\
(0.007)\end{array}$ \\
\hline F Age & $\begin{array}{l}-0.012^{* * *} \\
(0.004)\end{array}$ & $\begin{array}{c}0.003 \\
(0.006)\end{array}$ & $\begin{array}{r}0.000 \\
(0.005)\end{array}$ & $\begin{array}{l}-0.004 \\
(0.005)\end{array}$ & $\begin{array}{l}-0.004 \\
(0.005)\end{array}$ \\
\hline M Second union & $\begin{array}{l}-0.056^{*} \\
(0.034)\end{array}$ & $\begin{array}{l}-0.043 \\
(0.032)\end{array}$ & $\begin{array}{l}-0.034 \\
(0.031)\end{array}$ & $\begin{array}{l}-0.029 \\
(0.031)\end{array}$ & $\begin{array}{l}-0.032 \\
(0.035)\end{array}$ \\
\hline F Second union & $\begin{array}{l}0.095^{* * *} \\
(0.034)\end{array}$ & $\begin{array}{l}0.069 * * \\
(0.034)\end{array}$ & $\begin{array}{l}0.065^{* *} \\
(0.033)\end{array}$ & $\begin{array}{l}0.069 * * \\
(0.033)\end{array}$ & $\begin{array}{r}0.066 \\
(0.042)\end{array}$ \\
\hline M Parent & $\begin{array}{r}0.060 \\
(0.073)\end{array}$ & $\begin{array}{c}0.046 \\
(0.067)\end{array}$ & $\begin{array}{c}0.055 \\
(0.065)\end{array}$ & $\begin{array}{c}0.052 \\
(0.065)\end{array}$ & $\begin{array}{r}0.056 \\
(0.067)\end{array}$ \\
\hline F Parent & $\begin{array}{c}0.006 \\
(0.074)\end{array}$ & $\begin{array}{l}-0.008 \\
(0.069)\end{array}$ & $\begin{array}{c}0.002 \\
(0.067)\end{array}$ & $\begin{array}{l}-0.007 \\
(0.067)\end{array}$ & $\begin{array}{l}-0.006 \\
(0.063)\end{array}$ \\
\hline M Non-native & $\begin{array}{c}0.078 \\
(0.056)\end{array}$ & $\begin{array}{c}0.054 \\
(0.053)\end{array}$ & $\begin{array}{c}0.075 \\
(0.052)\end{array}$ & $\begin{array}{c}0.074 \\
(0.051)\end{array}$ & $\begin{array}{c}0.077 \\
(0.064)\end{array}$ \\
\hline F Non-native & $\begin{array}{l}-0.038 \\
(0.087)\end{array}$ & $\begin{array}{l}-0.115^{* *} \\
(0.057)\end{array}$ & $\begin{array}{l}-0.158^{* * *} \\
(0.056)\end{array}$ & $\begin{array}{l}-0.131 * * \\
(0.055)\end{array}$ & $\begin{array}{l}-0.128 * \\
(0.071)\end{array}$ \\
\hline Paris and sub. & $\begin{array}{l}0.066 * * \\
(0.031)\end{array}$ & $\begin{array}{l}0.075^{* *} \\
(0.030)\end{array}$ & $\begin{array}{l}0.073 * * \\
(0.030)\end{array}$ & $\begin{array}{l}0.085^{* * *} \\
(0.030)\end{array}$ & $\begin{array}{l}0.084^{* *} \\
(0.034)\end{array}$ \\
\hline M Education=medium & & $\begin{array}{l}0.116^{* * * *} \\
(0.035)\end{array}$ & $\begin{array}{l}0.096 * * * \\
(0.034)\end{array}$ & $\begin{array}{l}0.095^{* * * *} \\
(0.034)\end{array}$ & $\begin{array}{l}0.095^{* * *} \\
(0.034)\end{array}$ \\
\hline M Education =high & & $\begin{array}{l}0.151 * * * \\
(0.038)\end{array}$ & $\begin{array}{l}0.128 * * * \\
(0.037)\end{array}$ & $\begin{array}{l}0.136 * * * \\
(0.036)\end{array}$ & $\begin{array}{l}0.138 * * * \\
(0.044)\end{array}$ \\
\hline F Education =medium & & $\begin{array}{l}-0.108^{* * *} \\
(0.033)\end{array}$ & $\begin{array}{l}-0.081 * * \\
(0.032)\end{array}$ & $\begin{array}{l}-0.075 * * \\
(0.031)\end{array}$ & $\begin{array}{l}-0.075^{* *} \\
(0.030)\end{array}$ \\
\hline F Education =high & & $\begin{array}{l}-0.244^{* * *} \\
(0.039)\end{array}$ & $\begin{array}{l}-0.179 * * * \\
(0.039)\end{array}$ & $\begin{array}{l}-0.173^{* * *} \\
(0.034)\end{array}$ & $\begin{array}{l}-0.173 * * * \\
(0.036)\end{array}$ \\
\hline M Real experience & & $\begin{array}{l}-0.006 \\
(0.005)\end{array}$ & $\begin{array}{l}-0.010 * * \\
(0.005)\end{array}$ & $\begin{array}{l}-0.012 * * \\
(0.005)\end{array}$ & $\begin{array}{l}-0.012 * \\
(0.007)\end{array}$ \\
\hline F Real experience & & $\begin{array}{l}-0.016 * * * \\
(0.006)\end{array}$ & $\begin{array}{l}-0.006 \\
(0.006)\end{array}$ & $\begin{array}{l}-0.003 \\
(0.005)\end{array}$ & $\begin{array}{l}-0.003 \\
(0.005)\end{array}$ \\
\hline $\mathrm{M}$ health problems during lifetime & & $\begin{array}{l}-0.015 \\
(0.036)\end{array}$ & $\begin{array}{l}-0.032 \\
(0.035)\end{array}$ & $\begin{array}{l}-0.030 \\
(0.035)\end{array}$ & $\begin{array}{l}-0.029 \\
(0.032)\end{array}$ \\
\hline $\mathrm{F}$ health problems during lifetime & & $\begin{array}{c}0.064^{*} \\
(0.036)\end{array}$ & $\begin{array}{c}0.064^{*} \\
(0.035)\end{array}$ & $\begin{array}{c}0.067^{*} \\
(0.035)\end{array}$ & $\begin{array}{c}0.069 * \\
(0.040)\end{array}$ \\
\hline M Tenure & & & $\begin{array}{c}0.003^{*} \\
(0.002)\end{array}$ & $\begin{array}{c}0.003^{*} \\
(0.002)\end{array}$ & $\begin{array}{c}0.003^{*} \\
(0.002)\end{array}$ \\
\hline F Tenure & & & $\begin{array}{l}-0.006^{* * *} \\
(0.002)\end{array}$ & $\begin{array}{l}-0.006^{* *} \\
(0.002)\end{array}$ & $\begin{array}{l}-0.006^{* *} \\
(0.002)\end{array}$ \\
\hline M Position with responsibilities & & & $\begin{array}{l}0.123^{* * *} \\
(0.023)\end{array}$ & $\begin{array}{l}0.121^{* * *} \\
(0.023)\end{array}$ & $\begin{array}{l}0.121^{* * *} \\
(0.023)\end{array}$ \\
\hline F Position with responsibilities & & & $\begin{array}{l}-0.136^{* * *} \\
(0.030)\end{array}$ & $\begin{array}{l}-0.130 * * * \\
(0.030)\end{array}$ & $\begin{array}{l}-0.130 * * * \\
(0.034)\end{array}$ \\
\hline M Public sector & & & $\begin{array}{l}0.077^{* * * *} \\
(0.027)\end{array}$ & $\begin{array}{l}0.080 * * * \\
(0.027)\end{array}$ & $\begin{array}{l}0.080 * * * \\
(0.027)\end{array}$ \\
\hline
\end{tabular}


F Public sector

M firm $<50$ employees

F firm $<50$ employees

\begin{tabular}{llllll} 
Inverse Mill's ratio & -0.095 & 0.037 & 0.071 & -0.180 & $-0.198^{*}$ \\
& $(0.224)$ & $(0.098)$ & $(0.095)$ & $(0.110)$ & $(0.108)$ \\
Constant & -0.006 & $-0.340^{* *}$ & $-0.325^{* *}$ & $-0.287^{* *}$ & $-0.290^{*}$ \\
& $(0.065)$ & $(0.136)$ & $(0.135)$ & $(0.130)$ & $(0.162)$ \\
\hline F-stat first stage & & & & & 13.95 \\
$R^{2}$ & 0.03 & 0.09 & 0.15 & 0.16 & 0.16 \\
$N$ & 1,601 & 1,601 & 1,601 & 1,601 & 1,601 \\
\hline
\end{tabular}

$\begin{array}{lll}-0.115^{* * *} & -0.112^{* * *} & -0.112^{* * *} \\ (0.025) & (0.025) & (0.025) \\ -0.047^{* *} & -0.046^{* *} & -0.046^{* *} \\ (0.023) & (0.023) & (0.022) \\ 0.085^{* * *} & 0.086^{* * *} & 0.086^{* * *} \\ (0.022) & (0.022) & (0.022)\end{array}$

Source: Families and Employers Survey, $2004-2005$ (INED). ${ }^{*} p<0.1{ }^{* *} p<0.05 ;{ }^{* *} p<0.01$ 